\title{
Molecular phylogeny and species delimitation of the freshwater prawn Macrobrachium pilimanus species group, with descriptions of three new species from Thailand
}

\author{
Warut Siriwut $^{1}$, Ekgachai Jeratthitikul ${ }^{1}$, Somsak Panha ${ }^{2}$, Ratmanee Chanabun ${ }^{3}$, Chirasak Sutcharit ${ }^{\text {Corresp. } 2}$ \\ 1 Department of Biology, Faculty of Science, Mahidol University, Bangkok, Thailand \\ 2 Department of Biology, Faculty of Science, Chulalongkorn University, Bangkok, Thailand \\ 3 Faculty of Agricultural Technology, Sakon Nakhon Rajabhat University, Sakhon Nakhon, Thailand \\ Corresponding Author: Chirasak Sutcharit \\ Email address: chirasak.s@chula.ac.th
}

Specific status and species boundaries of several freshwater prawns in the Macrobrachium pilimanus species group remain ambiguous, despite the taxonomic re-description of type materials and additional specimens collected to expand the boundaries of some species. In this study, the "pilimanus" species group of Macrobrachium sensu Johnson (1958) was studied using specimens collected from montane streams of Thailand. Molecular phylogenetic analyses based on sequences of three molecular markers (COI, 16S and 18S rRNA) were performed. The phylogenetic results agreed with morphological identifications, and indicated the presence of at least nine putative taxa. Of these, six morphospecies were recognised as $M$. malayanum, $M$. forcipatum, $M$. dienbienphuense, $M$. hirsutimanus, $M$. eriocheirum, and $M$. sirindhorn. Furthermore, three morphologically and genetically distinct linages were detected, and are described herein as $\boldsymbol{M}$. naiyanetri Siriwut sp. nov., M. palmopilosum Siriwut sp. nov. and M. puberimanus Siriwut sp. nov. The taxonomic comparison indicated wide morphological variation in several species and suggested additional diagnostic characters that are suitable for use in species diagnoses, such as the shape and orientation of fingers, the rostrum form, and the presence or absence of velvet pubescence hairs and tuberculated spinulation on each telopodite of the second pereiopods. The "pilimanus" species group was portrayed as non-monophyletic in both $\mathrm{ML}$ and $\mathrm{BI}$ analyses. The genetic structure of different geographical populations in Thailand was detected in some widespread species. The species delimitation based on the four delimitation methods (BIN, ABGD, PTP and GMYC) suggested high genetic diversity of the "pilimanus" species group and placed the candidate members much higher than in previous designations based on traditional morphology. This finding suggests that further investigation of morphological and genetic diversity of Southeast Asian freshwater prawns in the genus Macrobrachium is still required to provide a comprehensive species list to 
guide efforts in conservation and resource management. 
1 Molecular phylogeny and species delimitation of the freshwater 2 prawn Macrobrachium pilimanus species group, with descriptions of 3 three new species from Thailand

4

5 Warut Siriwut $^{1}$, Ekgachai Jeratthitikul ${ }^{1}$, Somsak Panha ${ }^{2}$, Ratmanee Chanabun ${ }^{3}$ and Chirasak

6 Sutcharit $^{2 *}$

7

$8{ }^{1}$ Department of Biology, Faculty of Science, Mahidol University, Bangkok,

9 Thailand ${ }^{2}$ Department of Biology, Faculty of Science, Chulalongkorn University, Bangkok,

10 Thailand

$11{ }^{3}$ Faculty of Agricultural Technology, Sakon Nakhon Rajabhat University, Sakhon Nakon,

12 Thailand*Corresponding author

13 E-mail:jirasak4@yahoo.com 


\author{
45 Abstract \\ Specific status and species boundaries of several freshwater prawns in the Macrobrachium \\ pilimanus species group remain ambiguous, despite the taxonomic re-description of type \\ materials and additional specimens collected to expand the boundaries of some species. In this \\ study, the "pilimanus" species group of Macrobrachium sensu Johnson (1958) was studied using \\ specimens collected from montane streams of Thailand. Molecular phylogenetic analyses based \\ on sequences of three molecular markers (COI, 16S and 18S rRNA) were performed. The \\ phylogenetic results agreed with morphological identifications, and indicated the presence of at \\ least nine putative taxa. Of these, six morphospecies were recognised as M. malayanum, $M$. \\ forcipatum, $M$. dienbienphuense, $M$. hirsutimanus, $M$. eriocheirum, and $M$. sirindhorn. \\ Furthermore, three morphologically and genetically distinct linages were detected, and are \\ described herein as M. naiyanetri Siriwut sp. nov., M. palmopilosum Siriwut sp. nov. and $M$. \\ puberimanus Siriwut sp. nov. The taxonomic comparison indicated wide morphological \\ variation in several species and suggested additional diagnostic characters that are suitable for \\ use in species diagnoses, such as the shape and orientation of fingers, the rostrum form, and the \\ presence or absence of velvet pubescence hairs and tuberculated spinulation on each telopodite \\ of the second pereiopods. The "pilimanus" species group was portrayed as non-monophyletic in \\ both ML and BI analyses. The genetic structure of different geographical populations in Thailand \\ was detected in some widespread species. The species delimitation based on the four delimitation \\ methods (BIN, ABGD, PTP and GMYC) suggested high genetic diversity of the "pilimanus" \\ species group and placed the candidate members much higher than in previous designations \\ based on traditional morphology. This finding suggests that further investigation of \\ morphological and genetic diversity of Southeast Asian freshwater prawns in the genus \\ Macrobrachium is still required to provide a comprehensive species list to guide efforts in \\ conservation and resource management.
}


72 Introduction

73

74

75

76

77

78

79

80

81

82

83

84

85

86

87

88

89

90

91

92

93

94

95

96

97

98

99

100

101

102

103

104

105

106

107

108

109

110

111

112

113

114

115

116

117

Macrobrachium prawns have received particular attention worldwide because of their economic value and their use as model organisms for biogeographical study of evolutionary diversification (de Bruyn et al. 2014). Recently, evidence of high genetic diversity and species richness in some freshwater and terrestrial invertebrates in mainland Southeast Asia was revealed by integrating morphological and molecular systematic methods. Systematic studies of Asian shrimp and prawn species have been increasingly pursued due to evidence of unreported species and underestimation of genetic diversity (Bernardes et al. 2017; de Bruyn \& Mather 2007; de Mazancourt et al. 2019; von Rintelen et al. 2007). New native species have been reported from several remote areas throughout both continental and insular Asia (Cai \& Ng 2002; Chong 1989; Saengphan et al. 2018; Saengphan et al. 2019; Wowor \& Short 2007; Xuân 2012).

In the past, Thai freshwater prawn and shrimp fauna were referred to in some taxonomic revisions among the oriental crustacean fauna (Holthuis 1950; Holthuis 1955; Johnson 1963).Twenty-eight described species of freshwater prawns of the genus Macrobrachium Spence Bate, 1868 have been reported in Thailand (Cai et al. 2004; Naiyanetr 2001; Naiyanetr 2007; Saengphan et al. 2018; Saengphan et al. 2019). All Macrobrachium species in Thailand are found abundantly within two major riverine systems, namely the Chaophraya and Greater Mekong Basins, as reported by previous taxonomic studies (Cai \& Ng 2002; Hanamura et al. 2011). Cai et al. (2004) reported that the M. pilimanus species group sensu Johnson (1960) consisted of 12 species: M. pilimanus (De Man, 1879), M. leptodactylus (De Man, 1892), M. hirsutimanus (Tiwari, 1952), M. dienbienphuense Dang and Nguyen, 1972, M. eriocheirum Dai, 1984 (currently treated as a synonym of M. dienbienphuense), M. ahkowi Chong and Khoo, 1987, M. gua Chong, 1989, M. forcipatum Ng, 1995, M. platycheles Ou and Yeo, 1995, M. pilosum Cai and Dai, 1999, M. amplimanus Cai and Dai, 1999, and M. sirindhorn Naiyanetr, 2001. Later, five new species were added to this species group: M. dalatense Xuan, 2003 from southern Vietnam, three species from Indonesia, namely M. urayang Wowor and Short, 2007, M. kelianense Wowor and Short, 2007, M. empulipke Wowor, 2010 and one troglobitic species, $M$. spelaeus Cai and Vidthayanon, 2016 from Thailand. The diagnostic characters for this group were critically debated due to complicated morphological variation. However, several species exhibit compatible patterns by having a short blade-like rostrum, cupped or slightly elongated carpus, swollen merus of the second pereiopods, and the presence of velvet setae on the telopodites of the second pereiopods (Cai et al. 2004; Chong 1989; Holthuis 1979; Johnson 1960; Ng 1994).

Several species in the "pilimanus" species group exhibit widespread distribution, such as M. dienbienphuense, M. amplimanus, M. hirsutimanus and M. forcipatum. In contrast, there are also some species reported to be endemic and limited to a narrow territory, including $M$. sirindhorn and M. spelaeus, which are restricted to areas in northern Thailand (Cai and Vidthayanon 2016). Detailed information on the distribution range and type locality of all nominal taxa in "pilimanus" species group has been provided in Table S1. The limitation of using traditional taxonomic characters for species identification in the "pilimanus" group has been acknowledged, as several species exhibit similar morphological patterns and have few diagnostic characters (Holthuis 1950; Johnson 1960; Johnson 1963; Ou \& Yeo 1995; Yeo 1999). The diagnosis of nominal taxa has usually been based on a combination of quantitative and qualitative characters such as the proportion of rostrum, podomeres of second pereiopods and the presence and absence of pubescence on fingers, palm and merus of second pereiopods. Because

Peer] reviewing PDF | (2020:03:47081:1:2:NEW 9 Sep 2020) 
118 of high morphological variation, the species diversity of $M$. pilimanus group has been debated 119 (Cai et al. 2004; Cai \& Liang 1999; Hanamura et al. 2011; Holthuis 1952; Johnson 1960; Li 120 2007; Wowor 2010; Wowor \& Short 2007). Previously, the phylogenetic position refered by

\section{some $M$. pilimanus members also indicated the unclear relationship between congeneric species} in genus Macrobrachium such as M. niphanae, M. yui and M. neglectum (Liu et al. 2007; Wowor et al. 2009).

Several taxonomic identifications of prawns in genus Macrobrachium were based on the combination of traditional morphology. The re-examination of type specimens and additional museum collections has been done in some Macrobrachium species (Cai et al. 2004; Cai \& Shokita 2006; Holthuis 1952). The comprehensive distribution and taxonomic status of several species are questionable due to limited material available from different geographical areas and their scattered distribution ranges (Cai \& Ng 2002; Hanamura et al. 2011; Johnson 1963). Although Thailand is located in the center of mainland Southeast-Asia, its freshwater fauna is likely under-reported, including Macrobrachium prawns in both major river basins. The lack of broad-scale specimen comparison and comprehensive data on geographical variation and genetic composition are of critical concern, given the obscure justification for their taxonomic boundaries (Castelin et al. 2017; Chen et al. 2015; Rossi \& Mantelatto 2013). As a result, classification and assignment of Macrobrachium species into a suitable species complex or species groups has generally been problematic (Johnson 1960; Wowor \& Ng 2007; Wowor \& Short 2007).

Molecular systematics based on DNA barcoding regions and species delimitation coupled with DNA sequence variation has been widely used to screen for putative species identification in some highly diversified decapod groups (Bernardes et al. 2017; de Mazancourt et al. 2019; Venera-Pontón et al. 2020). In this study, we integrate traditional taxonomic examination and molecular phylogeny using three molecular markers to delimit species boundaries and to illustrate the phylogenetic relationships within the "pilimanus" species group collected from Thailand, with further discussion of their distribution and phylogenetic position among mainland Southeast Asian species.

\section{Methodology}

\section{Field collecting and specimen preparation}

Prawn specimens were collected from riverine systems throughout Thailand. Field surveys were conducted to collect fresh specimens in some protected areas with permission from the Department of National Parks, Wildlife and Plant Conservation, Thailand (DNP 0907.4/14262). Some species previously described with the type locality in Thailand were recollected and used as additional topotype material for species identity in morphological and molecular examinations. The live habitus specimens were photographed in order to document body colouration, and then euthanised by the two-step method following AVMA Guidelines for the Euthanasia of Animals (AVMA 2013) before fixing in 95\% ethanol for long-term preservation. Animal use in this study strictly followed the protocols approved by Chulalongkorn University (Protocol Review No. 1723018) and Mahidol University-Institute Animal Care and Use Committee (MU-IACUC) under approval number MU-IACUC 2018/004. 
163

164

165

166

167

168

169

170

171

172

173

174

175

176

177

178

179

180

181

182

183

184

185

186

187

188

189

190

191

192

193

194

195

196

197

198

199

200

201

202

203

204

205

206

207

208

Collected prawn specimens were registered and housed at Chulalongkorn University Museum of Zoology, Bangkok, Thailand (CUMZ), and Mahidol University, Natural History Museum (MUNHM). Species identifications were made by comparison with previous taxonomic records of Macrobrachium prawns from Thailand and surrounding countries. Morphological characteristics of each species were observed by using stereo-microscope. Traditional and diagnostic characters for species identification were photographed with Cell'D imaging system. In addition, the fine detail of some morphological characters were illustrated by free-hand drawings to document their variation. For morphological variation analysis, constant characters were selected for study using classical landmark-based geometric morphometrics. The protocols used in this study followed Siriwut et al. (2015).

Species descriptions and technical terms used herein are based on previous taxonomic studies of Southeast Asian Macrobrachium species (Cai \& Dai 1999; Cai et al. 2004; Cai \& Ng 2002; Hanamura et al. 2011; Holthuis 1950; Wowor \& Short 2007; Xuân 2012). Abbreviations for terms used in the comparison table are as follows: Fin., fingers; Pal., palm; Carp., carpus; Mer., merus; Dt., teeth on dactylus; Pt., teeth on pollex. The rostrum teeth formula is the total number of dorsal teeth/total number of ventral teeth. Total body length (tl) used in the species description was measured from the end of the telson to the tip of the rostrum. Carapace length (cl) was measured from the dorso-posterior margin of the carapace to the end of the postantennular margin of the carapace. Rostrum length (rl) was measured from the tip of the rostrum to the posterior-most rostrum tooth. All characters are reported in millimeters.

\section{Nomenclatural acts}

The electronic version of this article in portable document format (PDF) will represent a published work according to the International Commission on Zoological Nomenclature (ICZN), and hence the new names contained in the electronic version are effectively published under that Code from the electronic edition alone. This published work and the nomenclatural acts it contains have been registered in ZooBank, the online registration system for the ICZN. The ZooBank LSIDs (Life Science Identifiers) can be resolved and the associated information viewed through any standard web browser by appending the LSID to the prefix http://zoobank.org/. The LSID for this publication is: urn:lsid:zoobank.org:pub:F94C18CF-8E07-4D4B-94ED4153854B237E. The online version of this work is archived and available from the following digital repositories: PeerJ, PubMed Central and CLOCKSS.

\section{DNA extraction and PCR}

All prawn samples used for molecular analysis in this study are listed in Table 1. Prawn tissueThe genomic DNA was extracted from abdominal muscle tissue by using Commercial DNA extraction kits (NucleoSpin Tissue kit; MACHEREY-NAGEL). The concentration of total genomic DNA was measured and visualised by gel electrophoresis. Three standard molecular loci for Macrobrachium were selected for phylogenetic study, including the barcode regions of mitochondrial cytochrome c oxidase subunit I (COI), 16S rRNA (16S), and nuclear 18S rRNA (18S). The criteria for DNA marker selection were 1) sequences of closely related taxa for sequence comparison are available in a public database such as GenBank and BOLD ((Liu et al. 2007; Wowor et al. 2009), 2) marker is commonly used for phylogenetic tree reconstruction of

Peer) reviewing PDF | (2020:03:47081:1:2:NEW 9 Sep 2020) 
genus Macrobrachium (Rossi et al. 2020; Saengphan et al. 2018; Saengphan et al. 2019) and 3) a sufficient amount of variation, conserved and parsimony informative sites for multi-locus phylogenetic study (Liu et al. 2017; Matzen da Silva et al. 2011; Pileggi \& Mantelatto 2010). The PCR primers used in amplification and sequencing are presented in Table 2. PCR reactions were incubated using T100 TM thermal cycler (BIO-RAD) with gradient temperature function. The components of the PCR mixture followed Siriwut et al. (2015). Reaction conditions for each molecular locus were based on previous phylogenetic studies of shrimp and prawns (Pileggi \& Mantelatto (2010); Rossi \& Mantelatto (2013); von Rintelen et al. (2007); Wowor et al. (2009). Successfully amplified PCR products were checked by using fluorescence-enhanced agarose gel electrophoresis.

The PEG precipitation method was used to purify the PCR products. The purified PCR products were sequenced at Bioneer Inc. (Korea). Raw sequences were aligned with libraries in GenBank using the BLASTn algorithm to verify the organism's identity. Sequence configuration was done in Sequence Navigator (Parker 1997). Sequence annotation and trimming were carried out in MEGA 7 (Kumar et al. 2016) using MUSCLE (Edgar 2004). Sequence format was constructed using MEGA 7 and Mesquite (Maddison \& Maddison 2017). All newly obtained nucleotide sequences were deposited in the GenBank database under GenBank submission numbers MT235929-MT235968 for COI, MT248221-MT248260 for 16S, and MT248181MT248220 for 18S (in Table 1).

\section{Phylogenetic reconstruction and species delimitation}

For our phylogenetic study, the dataset of each partial gene was compiled from the newly amplified sequences from fresh material and available sequences from public databases (NCBI and BOLD). The number of sequences used per marker are as follows: 57 sequences for COI, 79 sequences for $16 \mathrm{~S}$, and 53 sequences for $18 \mathrm{~S}$. For the concatenated dataset, the number of sequences used for each marker was optimized in order to average individual sequence length of sample. Samples from public databases were included in the concatenated dataset when at least two of the three marker sequences were available. In total, 54 sequenced samples were used in phylogenetic tree reconstruction based on the concatenated dataset. A list of outgroups and other Macrobrachium taxa in this study is provided in Table S2.

Maximum likelihood (ML) and Bayesian inference (BI) methods were applied to reconstruct phylogenetic trees. Thehe concatenated dataset of three genetic markers with the partitioned file for nucleotide substitution model fit was prepared using Kakusan 4 (Tanabe 2007). The alternative substitution model for phylogenetic tree reconstruction was tested by using JModelTest v.1.7 (Posada 2008). For ML analysis, RAxML 8.0.0v (Stamatakis 2006) with default parameter set was used to reconstruct phylogenetic tree. The ML tree topology was confidential tested under 1,000 bootstrap replicates. Bayesian inference tree was sampled in MrBayes, ver. 3.2.6. (Ronquist et al. 2012). Markov chain Monte Carlo (MCMC) chains were configured to run for 10 million generations, and trees were saved each 500 generations. Twentyfive percent of tree samples were discarded under burn-in fragment parameter settings. The consensus tree was generated from a 50\% majority rule. The annotation and illustration of clade and branch length were configured by FigTree (Rambaut 2009). Node creditable values, Bootstrap (ML) and posterior probablility (BI), are labelled on the clade based on the acceptance criteria as follow: bootstrap values exceed 70\% (Larget \& Simon 1999)and posterior probabilities exceed 0.95 (Huelsenbeck \& Hillis 1993). A p-distance method was used to 
255

256

257

258

259

260

261

262

263

264

265

266

267

268

269

270

271

272

273

274

275

276

277

278

279

280

281

282

283

284

285

286

287

288

289

290

291

292

293

294

295

296

297

calculate the genetic distance of all gene fragments in MEGA 7.. The nMDS plot of pairwise sequnce results was constructed for COI and $16 \mathrm{~S}$ by using PAST program (Hammer et al. 2001). Species delimitation was performed using four standardised methods for automatic species delimitation to detect the Molecular Operational Taxonomic Units (MOTUs): automated barcode gap (ABGD by Puillandre et al. (2012)), Bayesian implementation of Poisson Tree Processes model (bPTP by Zhang et al. (2013)), the multi-rate Poisson Tree Processes (mPTP by Kapli et al. (2017)) and the Generalized Mixed Yule Coalescent model (GMYC by Pons et al. (2006)). Each gene dataset was tested separately as a single partition. For the COI dataset, the sequence analysis function in BOLD including BIN clustering was implemented to designate the possible putative species in sequence dataset. For the ABGD method, the intra-specific variation obtained from each molecular marker dataset was calculated in MEGA7 and the optimised barcode relative gap was calculated using the ABGD online server (http://wwwabi.snv.jussieu.fr/public/abgd/abgdweb.html). The PTP analysis was conducted under the Maximum likelihood algorithm using a web server (https://species.h-its.org/gmyc/;by Zhang et al. (2013)). The best-scoring tree dataset was estimated under $95 \%$ confidence of statistical probability. In the GMYC method, the starting tree was randomly sampled and manually calculated under a suitable model for the construction of an ultra-metric tree using BEAST package v1.10.4 (Drummond \& Rambaut 2007; Suchard et al. 2018) or implemented in CIPRES (Miller et al. 2010). The maximum clade credibility tree from each gene analysis was summarised in TreeAnnotator v1.10.4 and was analysed under the GMYC species delimitation approach using an online server. The results of automatic delimitation methods were compared 1) with the morphological identification of genus Macrobrachium species based on their original descriptions and with recent taxonomic reviews of nominal taxa to match each clade under biological species and 2) with molecular phylogenetic partional analysis based on the three concatenated gene datasets.

\section{Results}

\section{Phylogenetic relationship and species delimitation of Thai "pilimanus" species group}

Thirty-nine sequences from three partial genes were successfully amplified and comparatively aligned. The sampling locality of each species is illustrated in Figure 1. The annotation of each partial gene sequence is described in Table 3. The genetic distance of each mitochondrial DNA dataset (COI and 16S) and nuclear 18S dataset was calculated with 1,000 bootstrap replicates. The estimates of inter- and intra-specific variation of all representative taxa, are listed together with standard deviation in Table S3. Interspecific variation between members of the "pilimanus" species group found in Thailand was $9.8-23.3 \%$ for COI, $2.3-7.7 \%$ for $16 \mathrm{~S}$ and $0.2-11 \%$ for $18 \mathrm{~S}$. Intraspecific variation was $0.45-8.36 \%$ for COI, $0-3.5 \%$ for $16 \mathrm{~S}$ and 0 $2.1 \%$ for $18 \mathrm{~S}$. Non-metric multidimensional scaling (nMDS) plots representing pairwise comparison of $\mathrm{COI}$ and $16 \mathrm{~S}$ sequences used for single gene analysis (including sequences from NCBI and BOLD) were generated (see Fig. S1 and table S4-5). 
298

299

300

301

302

303

304

305

306

307

308

309

310

311

312

313

314

315

316

317

318

319

320

321

322

323

324

325

326

327

328

329

330

331

332

333

334

335

336

337

338

339

340

341

342

343

The phylogenetic tree based on the concatenated dataset of three partial genes indicated the non-monophyletic relationship of genus Macrobrachium because two outgroups (Coralliocaris superba and Exopalaemon styliferus) were nested inside and represented polytomy (clade A in Figure 2). This result was also found in single-locus phylogenetic analyses (see Fig. S2-3). After being rooted by outgroups and additional "pilimanus" members ( $M$. pilimanus and M. urayang), most "pilimanus" members except an OUT of M. urayang from Indonesia showed a monophyletic relationship and nested with $M$. niphanae, with values showing support in both BI and ML analyses (clade B). The monophyletic relationship of most "pilimanus" members was indicated in clade C, and they were separated into two linages. The clade D linage comprised six species: M. malayanum, $M$. naiyanetri sp. nov., $M$. forcipatum, $M$. sirindhorn, M. pilimanus, and M. palmopilosum sp. nov. The monophyly of M. malayanum was detected and it was positioned as a basal clade to other congeneric species within this linage. The phylogenetic tree also indicated the nesting of $M$. sirindhorn with two other species, namely $M$. pilimanus and M. palmopilosum sp. nov., although this clade was not supported by statistical tests. In clade F, specimens of $M$. forcipatum, M. naiyanetri sp. nov. and one sample referred to as $M$. aff. pilimanus formed a monophyletic group, with statistical support from both ML and BI analyses. Macrobrachium naiyanetri sp. nov. and $M$. aff. pilimanus formed a monophyletic group, while $M$. forcipatum was placed at the base of the clade. The monophyly of $M$. naiyanetri sp. nov. was further separated into two distinct geographical clades: a clade including samples from the southern peninsulaof Thailand plus $M$. aff. pilimanus from Khammouane, Laos, and a second clade of two samples from eastern Thailand.

In clade E, Macrobrachium hirsutimanus, M. eriocheirum, M. dienbienphuense and $M$. puberimanus sp. nov. were nested as a monophyletic group with statistical support in both ML and BI. Within this clade, the phylogenetic positions of M. hirsutimanus and M. eriocheirum were uncertain due to low support of clade composition; however, the monophyletic relationship of representative OTUs was indicated consistently in ML and BI for both taxa. Clade G included two species with similar morphology, $M$. dienbienphuense and $M$. puberimanus sp. nov.; the monophyly of each species is questionable due to two sequences of $M$. dienbienphuense from the public database nested with $M$. puberimanus sp. nov. In the major clade of $M$. dienbienphuense, two genetically distinct subclades were found with statistical support.

Species delimitation of each partial sequence dataset indicated a different number of candidate taxa, and there was also variation by calculation approach (Figure 2). The BIN clustering method in BOLD indicated 29 putative species for the COI dataset. The ABGD method indicated 19 species in COI, 19 species in $16 \mathrm{~S}$ and 9 species in $18 \mathrm{~S}$. In the Bayesian Poisson Tree Process (bPTP), the clustering result indicated 20 species in COI, 19 species in $16 \mathrm{~S}$ and 15 species in 18S. The multi-rate Poisson Tree Process (mPTP) indicated 14 species in COI, 2 species in $16 \mathrm{~S}$ and 1 species in $18 \mathrm{~S}$. In the GMYC analysis, the clustering method indicated 18 species in COI, 21 species in $16 \mathrm{~S}$ and 3 species in $18 \mathrm{~S}$, based on the ultrametric tree. The separation evidence (red box) detected eight taxa while lumping evidence (blue box) was found mainly in the clade of $M$. puberimanus sp. nov. and from two samples of $M$. dienbienphuense from the public database.

\section{Systematic diversity of the "pilimanus" species group in Thailand}


344

In this study, field collection and taxonomic identification of Thai Macrobrachium indicated nine morphological species, three of which are totally distinct from the others by both morphology and molecular delimitation. Six described species, namely M. hirsutimanus, $M$. eriocheirum, $M$. dienbienphuense, M. forcipatum, M. malayanum and $M$. sirindhorn were reconfirmed with previous taxonomic studies. The distribution of these six species mainly included montane tributary streams, while some species such as $M$. dienbienphuense also occupied larger rivers. The geographical distribution of "pilimanus" members is illustrated in Figure 1. Based on this study and previous taxonomic records of Macrobrachium prawns in the "pilimanus" group, Thailand hosts eleven species. However, only the three new species found in this study will be described here, along with their phylogenetic placement, genetic relationship and geographical distribution.

Taxon names declaration: The proposed three new species herein are attributed to Warut Siriwut; thus, the authorship of these new taxon names should be cited as M. naiyanetri Siriwut in Siriwut et al., 2020, M. palmopilosum Siriwut in Siriwut et al., 2020 and M. puberimanus Siriwut in Siriwut et al., 2020.

\section{Taxonomic account}

Palaemonidae Rafinesque, 1815

Macrobrachium Spence Bate, 1868

\section{Macrobrachium naiyanetri Siriwut sp. nov.}

ZooBank ID: urn:lsid:zoobank.org:act:22EBCA17-2E29-4193-9D9E-87CABCD65D7D Figures $3 \mathrm{~A}$ and 4

Type locality. A large and shallow stream with large gravels at Hui Prik, Cha-wang District, Nakhon Si Thammarat Province, Thailand.

Type examined. Holotype: CUMZ MP00001, one male spm. from Hui Prik, Cha-wang District, Nakhon Si Thammarat Province (M128 in molecular analysis). Paratype: CUMZ MP00002, four male spms from the same locality as holotype (M127, M154 and M155). CUMZ MP00003, nineteen male and nine female spms from the same locality as holotype.

Additional material. CUMZ MP00004, two male spms from Khao Banchob Waterfall, Makham District, Chanthaburi Province (M102). CUMZ MP00005, one male spm. from Klong Rattaphum, Rattaphum District, Songkhla Province (M134). CUMZ MP00006, twenty-six male and nine ovigerous female spms from Klong Krabiead, Hui Prik, Cha-wang District, Nakhon Si Thammarat Province.

Diagnosis. Rostrum short and striate distally, not reach beyond the end of second telopodite of antennular peduncle. Rostral formula: 8-14/ 2-4 teeth. Small spinulation presents on anterolateral margin of carapace. Epistome trilobed. Second pereiopods slightly longer than body lenght, similar in shape, unequal in size. Second pereiopods with long setae,present on finger, palm, anterior inner part of carpus and merus. 10-18 teeth on figers. Carpus elongated or slightly cupped, shorter than fingers, palm and merus. All telopodites of second pereiopods covered with spinules. Thoracic sternites; T4 with postero submedial plate; T5 with transverse plate with 
390

391

392

393

394

395

396

397

398

399

400

401

402

403

404

405

406

407

408

409

410

411

412

413

414

415

416

417

418

419

420

421

422

423

424

425

426

427

428

429

430

431

432

433

434

435

median process. Second and third abdominal sternites with moderate triangular median process. Preanal carina present. Telson slightly short and stouth, surface glabrously, with long plumose seta and posterior projection with two long inner and two short outer spines. Uropods glabrous; uropodal diaeresis with inner moveable spine, equal to outer angle. Developed eggs large, approximate diameter $0.7 \mathrm{~mm}$, ovoid.

Composite description (type specimens in parentheses). A medium-sized Macrobrachium species, tl 30.6-54.2 $\mathrm{mm}$ (41.5 mm in holotype), with pale or brownish body colouration (Figs $3 \mathrm{~A})$.

Rostrum (Fig. 5C, D). Anteriorly striate and angled downward distally, rl 7.3-11.4 mm (10.8 mm in holotype) cl 6.7-13.0 $\mathrm{mm}$ (13.0 $\mathrm{mm}$ in holotype), and reaching not beyond the end of antennular peduncle. Dorsal part of rostrum with 8-14 (14 in holotype) teeth in total, 2-7 (6 in holotype) teeth present in postorbital area. Area with postorbital teeth covering nearly half of carapace length. Ventral part of rostrum with 2-4 (3) teeth, located about half-way distally.

Cephalon. Eye well developed. Ocular beak moderately developed, without laterally expanded tip. Postantennular carapace margin rounded. Cornea osculum longer than stalk. Antennular peduncle longer than wide, lateral carina well developed, dorsal carina without sinuous. Anterolateral part of carapace with antennal (one side without antennal spine in holotype). Small hepatic spines present lower than orbital angle; located behind ; branchiostegal suture present starting from hepatic spine to carapace margin. Spinulation present on ventro-lateral part of carapace (Fig. 5C). Epistome trilobed. Scaphocerite with margin concave laterally, distolateral tooth minutes and not reaching the end of lamella. Third maxilliped not reaching beyond antennal peduncle.

First pereiopods. Long and slender, reaching beyond the end of scaphocerite. Fingers about as long as palm; carpus longer than merus. Carpus, merus and ischium covered with small spinules. Scattered setae present on all segments but dense on finger and ischium.

Second pereiopods. Robust and longer than body length, similar in both shape and form; carpus of both major and minor second pereiopods extending beyond the end of scaphocerite.

Major second pereiopod (Fig. 5E, G). Spinulation present on all segments except fingers and palm. Fingers, palm, inner margins of carpus covered by fine setae. Dense, fine setae present on proximal part of finger. Merus with setae in some specimens. Fingers slender and longer than palm (17.6: $11.1 \mathrm{~mm})$, finger bending with gap and tips crossed when closed in males. Dactylus with 10-18 (15) prominent teeth, basal teeth larger than distal teeth, pollex with 10-18 (12) teeth (Fig. 5F). Teeth sub-equally distributed and concealed by long velvety setae, without oblique carina distally. Upper and lower margins of palm slightly expanded. Carpus elongated, shorter than merus (7.6: $11.8 \mathrm{~mm}$ in holotype). Merus equal to palm (11.8 $\mathrm{mm}$ in holotype). Ischium tapered, shorter than merus.

Minor second pereiopod (Fig. 5H). Similar in form but shorter than major cheliped, spinulation present on all segments except fingers and palm. Fine setae densely covering proximal part of fingers and palm. Dactylus with 6-18 small teeth, pollex with 8-15 small teeth. Teeth sub-equally 
436

437

438

439

440

441

442

443

444

445

446

447

448

449

450

451

452

453

454

455

456

457

458

459

460

461

462

463

464

465

466

467

468

469

470

471

472

473

474

475

476

477

478

479

480

distributed, only half of finger length, concealed by long, fine setae. Oblique carina present on distal part, about one-third of finger length. Carpus elongated, shorter than merus. Merus subcylindrical and equal to palm. Ischium tapered, shorter than merus.

Third pereiopods (Fig. 5I). Long and slender, propodus extending to the end of scaphocerite. Small spinulation present on all segments except ischium. A fine seta present on all segments. Dactylus short (2.1 mm in holotype) and curved, with dorsolateral setae; ventral carina well developed. Propodus long (4.6 mm in holotype), with 6-8 (7) ventral pairs of spines distributed along length of propodus; carpus shorter than propodus ( $3.1 \mathrm{~mm}$ in holotype), with dorsal projection on distal part. Merus longer than carpus (5.6 $\mathrm{mm}$ in holotype). Ischium shorter than merus and carpus (2.8 $\mathrm{mm}$ in holotype).

Fourth and fifth pereiopods. Dactylus extending to the end of scaphocerite. Spinulation present on all segments except ischium. Scattered fine setae present on all segments. Propodus with 5-7 pairs of ventral spines distributed along its length, 2 corner spines with grouped setae on distal part. Carpus shorter than propodus and merus, with dorsal projection on distal part. Ischium shorter than merus and carpus.

Thoracic sternum. T4 without median process. T5 with transverse plate without median process. T8 with posteromedial lobes in males.

Abdomen. Usually smooth, with tiny spinules on pleural margins of first and second abdominal segments. All abdominal sternites with transverse ridge. Second and third abdominal sternites with moderate triangular median process, subsequent segment without process. The sixth sternite with median obtuse process. Preanal carina present, with group of small setae at tip in males.

Telson (Fig. 5B). slightly short and stouth (5.9 mm in holotype), lateral margins straight. Cluster of setae present on antero-median part. Dorsal surface with 2 pairs of dorsal spines. Projection present on posterior margin, with two spines and plumose setae on each side, inner pair of posterior spines longer than outer spines.

Uropods (Fig. 5B). Uropodal diaeresis with inner moveable spine, equal to outer angle. Exopod longer than broad (5.5: $2.5 \mathrm{~mm}$ in holotype) and not reaching the end of endopods.

Etymology. The specific name naiyanetri is given in honor of Professor Phaibul Naiyanetr from Chulalongkorn University for his extensive contributions to the knowledge of crustacean fauna in Thailand.

Size. Males slightly larger than females; the largest male recorded being $54.2 \mathrm{~mm} \mathrm{tl}, 13.0 \mathrm{~mm} \mathrm{cl}$; the largest female $39.8 \mathrm{~mm} \mathrm{tl}, 9.5 \mathrm{~mm} \mathrm{cl}$ and egg size is $0.7 \mathrm{~mm}$ in diameter.

Distribution. Most populations are restricted to the southern part of Thailand; however, one specimen collected from Chantaburi Province extends its recorded distribution range to include the eastern part of Thailand. 
481

482

483

484

485

486

487

488

489

490

491

492

493

494

495

496

497

498

499

500

501

502

503

504

505

506

507

508

509

510

511

512

513

514

515

516

517

518

519

520

521

522

523

524

525

526

Remarks. Macrobrachium naiyanetri sp. nov. resembles other members of the "pilimanus" species group by having densely tufted setae on second pereiopods. The phylogenetic tree suggests the position of this new species as nesting with M. forcipatum. However, the distinguishing characteristics of $M$. naiyanetri sp. nov. used to separate it from the other congener species in southern Thailand (e.g. M. forcipatum, M. malayanum and M. hirsutimanus) are the carpus of the second major pereiopods that exhibit a slight cup-shape, the presence of dense stiff setae on the antero-inferior part of merus, and fingers of the second pereiopods being longer than palms. Moreover, the postorbital area contains more rostrum teeth (4-7 vs. 3-5 in $M$. forcipatum; 3-4 in M. malayanum; 3-5 in M. hirsutimanus). The adult size of M. naiyanetri sp. nov. is significantly larger and longer than the others $(\mathrm{tl})$. The dactylus contains $12-13$ prominent teeth (vs. 13-14 in M. forcipatum; 4-6 in M. malayanum; 15 in M. hirsutimanus). The size of major and minor second pereiopods is distinctly large in male specimens (vs. not distinct in other species). The carpus of the second pereiopod is slightly cupped (vs. cupped and stout in other species). The major second pereiopod in males is as long as tl. In addition, the species delimitation methods suggest two distinct evolutionary lineages of M. naiyanetri sp. nov. samples; the first lineage is composed of specimens from the western part of Khao Luang Range, whereas the second lineage contains two samples from the eastern part of Khao Luang Range (Songkhla Province) and from Chantaburi Province in eastern Thailand. Further investigation of population structure between these two distinct lineages is necessary to test whether or not this is the result of allopatric speciation.

\section{Macrobrachium palmopilosum Siriwut sp. nov. \\ ZooBank ID: urn:lsid:zoobank.org:act:8065628A-4EDF-49EF-BA5D-91588F53D284 \\ Figures $4 \mathrm{~B}$ and 6}

Type locality. A small and shallow stream with sand and gravel at Tat Man Waterfalls, Puea Sub-district, Chiang Klang District, Nan Province, Thailand.

Type examined. Holotype: CUMZ MP00007, one male spm. from Tat Man Waterfalls, Puea Sub-district, Chiang Klang District, Nan Province (M031). Paratype: CUMZ MP00008, twentyone male and twenty-seven female spms from the same locality as holotype.

Additional material. CUMZ MP00009, six male and two female spms from Sob-Pue, Sa-Iap Sub-district, Song District, Phrae Province (M030). CUMZ MP00010, twelve male and ten female spms from Mae Mang, Bo Kluea District, Nan Province (M011). CUMZ MP00011, one male spm. from Ban Pha Lak, Mueang District, Nan Province.

Diagnosis. Rostrum short, anteriorly striate and upward distally, not reaching to the end of second telopodite of antennular peduncle. Rostral formula: 10-12/ 2-3 teeth. Anterolateral margin of carapace with small spines. Epistome bilobed. The robust pair of second pereiopod longer than body length similar in shape, unequal in size. Densed andtufted setae present on both side of second pereiopods. Anterior part of carpus with setae. Fingers with 10-12 teeth. Carpus stoutand cupped, shorter than fingers, palm and merus. oSmall spinule present in posteriorpart of palm, entirely in carpus and merus. Thoracic sternites: T4 with posterior submedial plate; T5-T7 with transverse plate without median process; T8 with contiguous posteromedially anterior lobes, without median process. First to third abdominal sternites with moderate triangular median 
527 process. Preanal carina present. Telson moderately long, with scaterred plumose setae on dorsal 528 surface. Two pairs of spines present. Posterior projection present with two long inner and short

529

530

531

532

533

534

535

536

537

538

539

540

541

542

543

544

545

546

547

548

549

550

551

552

553

554

555

556

557

558

559

560

561

562

563

564

565

566

567

568

569

570

571

572

outer spines. Uropodal diaeresis spine shorter than outer angle. Egg size $1.3 \mathrm{~mm}$ in diameter.

Composite description (type specimens in parentheses). A medium-sized Macrobrachium species, tl 25.6-77.8 $\mathrm{mm}$ (57.3 $\mathrm{mm}$ in holotype), with pale or greenish-brown body colouration (Figs 4B).

Rostrum (Fig. 6C, D). Anteriorly striate and turned upward distally, rl 4.1-16.7 mm (11.7 in holotype) cl 5.9-20.4 $\mathrm{mm}$ (16.5 $\mathrm{mm}$ in holotype), and reaching not beyond the end of second segment of antennular peduncle. Dorsal part of rostrum with 10-12 (12 in holotype) teeth in total, 4-6 (5) teeth present in postorbital area. Area with postorbital teeth covers one-third of carapace length. Ventral part of rostrum with 2-3 (3) teeth, located about half-way to distal end.

Cephalon. Eye well developed. Ocular beak moderately developed, without laterally expanded tip. Postantennular carapace margin rounded. Cornea osculum shorter than stalk. Antennular peduncle longer than wide, lateral carina well developed, dorsal carina without sinuous. Anterolateral part of carapace with antennal spine. Small hepatic spines present lower than orbital angle and antennal spine. Branchiostegal suture starting from hepatic spine to carapace margin. A few scaterred spinules present on ventro-lateral part of carapace and branchiostegal regions of carapace (Fig. 6C). Ocular beak moderately developed, without laterally expanded tip. Epistome slightly bilobed. Scaphocerite with margin concave laterally, distolateral tooth minutes and not reaching the end of lamella. Third maxilliped not reaching beyond antennal peduncle..

First pereiopods. Long and slender, reaching beyond the end of scaphocerite. Fingers about as long as palm; carpus as long as merus. Small spinules present only on merus and ischium. Scattered setae present on all segments but dense area on distal part of finger and on entire ischium. The proximal part between palm and carpus with group of small setae.

Second pereiopods. Robust and longer than body length, similar in form; carpus of both major and minor second pereiopods extending beyond the end of scaphocerite.

Major second pereiopod (Fig. 6E, G). Spinulation present in all segments except fingers and anterior part of palm. Fingers, palm, inner margins of carpus covered by tufted setae. Merus without setae. Fingers subcylindrical, shorter than palm in length (13.8: $15.9 \mathrm{~mm}$.), closed fingers with gap and crossing distally. Dactylus with 10-12 (10) prominent teeth, basal teeth smaller than middle teeth, pollex with 10-11 (11) teeth (Fig. 5F). Teeth sub-equally distributed and concealed by long tufted setae, without oblique carina distally. Upper and lower margins of palm slightly expanded. Carpus cup-shaped, shorter than merus (7.1: 13.9 mm). Merus slightly shorter than palm (13.9: $15.9 \mathrm{~mm})$, stout and inflated laterally. Ischium tapered, shorter than merus.

Minor second pereiopod (Fig. 6H). Similar in form to major cheliped but smaller in size, spinulation present on all segments except fingers and anterior part of palm. Tufted setae covering fingers, palm and anterior part of carpus. Dactylus with 6-8 (6) small teeth, pollex with

Peer] reviewing PDF | (2020:03:47081:1:2:NEW 9 Sep 2020) 
573

574

575

576

577

578

579

580

581

582

583

584

585

586

587

588

589

590

591

592

593

594

595

596

597

598

599

600

601

602

603

604

605

606

607

608

609

610

611

612

613

614

615

616

617

618
7-8 (8) small teeth. Teeth distributed only on basal half of finger length, concealed by long, fine setae. Oblique carina present on distal part, about half of finger length. Carpus cup shaped, shorter than merus. Merus subcylindrical and as long as palm. Ischium tapered, shorter than merus.

Third pereiopods (Fig. 6I). Dactylus short (1.9 mm) and curved distally, with lateral short seta and ventral carina well developed. Propodus extending to the end of scaphocerite. Small spinulation present on all segments except ischium. A fine seta present on all segments. Propodus longer than dactylus (6.5: $1.9 \mathrm{~mm})$, with 5-6 (6) ventral pairs of spines distributed along length of propodus. Carpus shorter than propodus $(3.6 \mathrm{~mm})$, with dorsal projection on distal part. Merus longer than carpus $(6.5 \mathrm{~mm})$. Ischium shorter than merus and carpus $(3.3 \mathrm{~mm})$.

Fourth and fifth pereiopods. Dactylus extending to the end of scaphocerite. Spinulation present on all segments except ischium. Scattered fine setae present on all segments. Propodus with 5-6 pairs of ventral spines distributed along length of propodus. Propodus of fifth pereiopods with group of setae on distolateral part. Carpus shorter than propodus and merus, with dorsal projection on distal part. Ischium shorter than merus and carpus.

Thoracic sternum. T4-T8 with transverse plate without median process. T8 with posteromedial lobes in males.

Abdomen. Usually smooth, with tiny spinules on pleural margin of first to third abdominal segments in some specimens. All abdominal sternites with transverse ridge. First to third abdominal sternites with moderate triangular median process. Fifth sternite without median obtuse process. Preanal carina present, without small setae in males.

Telson (Fig. 6B). Moderately long (6.6 mm) Dorsal surface with 2 pairs of spines. Cluster of setae present on antero-median part. Projection present on posterior margin, with two spines and plumose setae on each side. The inner pair of posterior spines longer than outer spines.

Uropods (Fig. 6B). Uropodal diaeresis with inner moveable spine, shorter than outer angle. Exopod longer than broad (7.4: $4.3 \mathrm{~mm}$ ) and not reaching the end of endopods.

Etymology. The specific name "palmopilosum" is a compound Latin word with "palma" meaning palm of the hand and "pilosus" meaning hairy. This name refers to the tuft of hairs present on the palms of both second pereiopods.

Size. Males showing distinctly larger body size than females; the largest male recorded being $77.8 \mathrm{~mm}$ tl, $20.4 \mathrm{~mm} \mathrm{cl}$; the largest female $48.2 \mathrm{~mm} \mathrm{tl}, 12.0 \mathrm{~mm} \mathrm{cl}$ and egg size is $1.3 \mathrm{~mm}$ in diameter.

Distribution. Their distribution is restricted to the northern part of Thailand, Nan Province.

Remarks. The population of this new species is dominant in the Nan River Basin, especially living in clear, cool mountain streams. The colouration of this species varied from light pale to dark brownish; the banding pattern on the dorso-lateral part of tergum was observed in some

Peer] reviewing PDF | (2020:03:47081:1:2:NEW 9 Sep 2020) 
619

620

621

622

623

624

625

626

627

628

629

630

631

632

633

634

635

636

637

638

639

640

641

642

643

644

645

646

647

648

649

650

651

652

653

654

655

656

657

658

659

660

661

662

663

individuals. Macrobrachium palmopilosum sp. nov. shares several characteristics with $M$. eriocheirum, M. amplimanus and M. hirsutimanus. The character distinguishing $M$.

palmopilosum sp. nov. from $M$. eriocheirum and $M$. hirsutimanus is the presence of tufted setae on the palms of the second pereiopods. Macrobrachium hirsutimanus and M. eriocheirum exhibited tufted setae only on the anterior half of the palms, whereas M. palmopilosum sp. nov. had setae present over the entire surface of palms. Moreover, the spinulation on the anteromarginal surface of the carapace is always present in M. palmopilosum sp. nov. (absent in $M$. eriocheirum and $M$. hirsutimanus). The epistome of $M$. palmopilosum sp. nov. is slightly bilobed (trilobed in $M$. eriocheirum and $M$. hirsutimanus). The number of prominent teeth on fingers of M. palmopilosum sp. nov. is 6-12, whereas $M$. hirsutimanus has 12-20 teeth and $M$. eriocheirum has 12-15 teeth. Macrobrachium palmopilosum sp. nov. differs from $M$. amplimanus by having more rostrum teeth on the postorbital area (4-6 vs. 2-4), slightly smaller number of finger teeth on second pereiopods (10-12 vs. 11-15), the spinulation on palm surface of second pereiopods (present vs. absent), the length of fingers shorter than palm (vs. longer or as long as palm), and closed fingers with a gap (vs. without gap). The morphological comparisons of M. palmopilosum sp. nov. and other species are presented in Table 4.

The results of phylogenetic tree construction suggested that M. palmopilosum sp. nov. is closely related to M. naiyanetri sp. nov., as supported by all statistical tests. Macrobrachium palmopilosum sp. nov. shows distinctive differences from $M$. naiyanetri $\mathrm{sp}$. nov. by the stout cup shaped carpus of the major second pereiopods (vs. slightly elongated carpus in M. naiyanetri sp. nov.), the lack of setae on antero-inferior part of the merus of second pereiopods (vs. with dense setae on merus in M. naiyanetri sp. nov.), the inflated form of merus in M. palmopilosum sp. nov. (vs. subcylindrical in M. naiyanetri sp. nov.).

Tiwari (1952) described M. hirsutimanus based on specimens from northern Thailand (Doi Chuang) and later the type locality was replaced by the neotype designation (Nan Province; in Cai et al. (2004)). This taxonomic treatment advocates that the distribution of M. hirsutimanus coexists with M. palmopilosum sp. nov. In this study, the coexistence of these two species of prawns was confirmed in the Nan River Basin.

Macrobrachium puberimanus Siriwut sp. nov.

ZooBank ID: urn:1sid:zoobank.org:act:EE26BC6C-07F6-4C94-8B80-6F736B11F91A

Figures $4 \mathrm{C}$ and 7

Type locality. Mekong River at Wat Tha Khaek, Chiang Khan Sub-district, Chiang Khan District, Loei Province

Type examined. Holotype: CUMZ MP00012, one male spm. from Wat Tha Khaek, Chiang Khan Sub-district, Chiang Khan District, Loei Province (M099). Paratype: CUMZ MP00013, two male spms from the same locality as holotype.

Additional material. CUMZ MP00014, one male spm. from Phu Ruea District, Loei Province (M121). CUMZ MP00015, four male and twelve female spms from Nam Soam, Noan Thong Sub-district, Na Yung District, Udon Thani Province (M049). CUMZ MP00016, four male spms 
664 from Maekong River, Chiang Khan Sub-district, Chiang Khan District, Loei Province. CUMZ 665 MP00017, one male spm. from Maekong River, Pak Chom District, Loei Province.

666

Diagnosis. Rostrum moderately long, anteriorly striate and angled upward distally, reaching beyond the end of second segment of antennular peduncle. Rostral formula: 12-15/3 teeth. Carapace with small spinulation on anterolateral margin. Epistome trilobed. Second pereiopods strong and robust, shorter than body length, similar in shape and unequal in size. Long-tufted setae present on finger and palm of second pereiopods. Fingers of major second pereiopod with 11-16 teeth. Closded fingers with gap and crossing distally. Carpus elongated, shorter than palm. Spinulation present on dorso-inferior surface of palm, carpus, merus and ischium. Minor second pereiopod slight with tiny spines on each segment. Thoracic sternites: T4 with posterior submedial plate; T4-T7 with basolateral median plate without median notch; male T8 with posteromedially anterior lobes. Male and female without posteriorly medial process on T8. First to third abdominal sternites with moderate triangular median process. Preanal carina present. Telson moderately long, with long plumose setae on proximal part. Telson surface with two pairs of dorsal spines, terminal projection with two long inner and short outer spines. Uropodal

Rostrum short, anteriorly striate and upward distally, not reaching to the end of second telopodite of antennular peduncle. Rostral formula: 10-12/ 2-3 teeth. Anterolateral margin of carapace with small spines. Epistome bilobed. The robust pair of second pereiopod similar in shape, unequal in size. Densed andtufted setae present on both side of second pereiopods. Anterior part of carpus with setae. Fingers with 10-12 teeth. Carpus stoutand cupped, shorter than fingers, palm and merus. oSmall spinule present in posteriorpart of palm, entirely in carpus and merus. Thoracic sternites: T4 with posterior submedial plate; T5-T7 with transverse plate without median process; T8 with contiguous posteromedially anterior lobes, without median process. First to third abdominal sternites with moderate triangular median process. Preanal carina present. Telson moderately long, with scaterred plumose setae on dorsal surface. Two pairs of spines present. Posterior projection present with two long inner and short outer spines. Uropodal diaeresis spine shorter than outer angle. Egg size $1.3 \mathrm{~mm}$ in diameter.

Composite description (type specimens in parentheses). A medium-sized Macrobrachium species, tl 33.6-60.2 $\mathrm{mm}$ (60.2 $\mathrm{mm}$ in holotype), with pale or brownish-green body colouration (Figs 4C).

Rostrum (Fig. 7C, D). Anteriorly striate and angled upward distally, rl 7.4-12.7 mm (12.7 mm in holotype), cl 6.6-17.0 $\mathrm{mm}$ (17.0 $\mathrm{mm}$ in holotype), and reaching beyond the end second segment of antennular peduncle. Dorsal part of rostrum with 12-15 (13) teeth in total, 5-6 (5) teeth present in postorbital area. Area bearing postorbital teeth covering one-fourth of carapace length. Ventral part of rostrum with 3 (3) teeth, located about half-way to distal end.

Cephalon. Eye well developed. Postantennular carapace margin rounded. Cornea osculum as long as stalk. Antennular peduncle longer than wide, lateral carina slightly concave, dorsal carina 709 not sinuous. Sharp antennal and hepatic spines present at lower orbital angle; hepatic spine 
710

711

712

713

714

715

716

717

718

719

720

721

722

723

724

725

726

727

728

729

730

731

732

733

734

735

736

737

738

739

740

741

742

743

744

745

746

747

748

749

750

751

752

753

754

smaller, situated behind and below antennal spine; branchiostegal suture running from hepatic spine to anterior margin of carapace. Carapace without spinulation on ventro-lateral part and branchiostegal regions (Fig. 6C). Ocular beak moderately developed, without laterally expanded tip. Epistome trilobed. Scaphocerite, lateral margin slightly concave, distolateral tooth not reaching the end of lamella. Third maxilliped reaching beyond antennal peduncle and covering $75-80 \%$ of length of scaphocerite; ultimate slightly shorter than penultimate.

First pereiopods. Long and slender, reaching beyond the end of scaphocerite. Fingers about as long as palm; carpus as long as merus. Few setae scattered on all segments but dense on distal part of finger and on lower margin of ischium. Proximal part between palm and carpus without small setae.

Second pereiopods. Robust and slightly shorter than body length, similar in form but differing in size. Carpus of major second pereiopods extending beyond the end of scaphocerite.

Major second pereiopod (Fig. 7E, G). Spinulation present on dorso-inferior surface of palm, carpus, merus and ischium. Fingers, palm, inferior margins of carpus covered with few tufted setae. Merus without tufted setae anteriorly. Fingers sharp and subcylindrical, longer than palm in length (19.7: $15.3 \mathrm{~mm}$ ), closed fingers with gap and crossing distally. Dactylus with 11-16 (16) prominent teeth, basal teeth slightly smaller than distal teeth, pollex with 10-14 (14) teeth (Fig. 7F). Teeth sub-equally distributed and concealed by long tufted setae, with oblique carina distally, about $15-20 \%$ of finger length. Upper and lower margins of palm not expanded. Carpus slightly elongated, shorter than merus $(9.2: 16.6 \mathrm{~mm})$. Merus subcylindrical, as long as palm or shorter (16.6 vs $15.3 \mathrm{~mm}$ ). Ischium tapered, shorter than merus.

Minor second pereiopod (Fig. 7G). Short and smaller than major cheliped, spinulation absent in all segments. Few tufted setae covering fingers and palm. Dactylus with 6-8 (6) small teeth, pollex with 5-11 (7) small teeth. Teeth distributed only on basal half of finger length, concealed by fine setae. Oblique carina present on distal two-thirds of finger length. Carpus elongated, shorter than merus. Merus subcylindrical and as long as palm. Ischium tapered, shorter than merus.

Third pereiopods (Fig. 7I). Long and slender; propodus extending to the end of scaphocerite. Small spinulation absent in all segments. A fine seta present on all segments. Dactylus short and curved $(2.2 \mathrm{~mm})$, with dorsolateral setae on distal part, ventral carina well developed. Propodus longer than dactylus $(6.5: 1.8 \mathrm{~mm})$, with 5-7 ventral pairs of spines distributed along length of propodus. Carpus shorter than propodus $(3.5 \mathrm{~mm})$, with dorsal projection on distal part. Merus longer than carpus $(8.6 \mathrm{~mm})$. Ischium shorter than merus $(3.2 \mathrm{~mm})$.

Fourth and fifth pereiopods. Dactylus extending to the end of scaphocerite. Spinulation absent on all segments. Few fine setae present, scattered on all segments. Propodus with 5-6 pairs of ventral spines distributed along length of propodus. Propodus of fifth pereiopods with group of setae on distolateral part. Carpus shorter than propodus and merus, with dorsal projection on distal part. Ischium shorter than merus. 
755

756

757

758

759

760

761

762

763

764

765

766

767

768

769

770

771

772

773

774

775

776

777

778

779

780

781

782

783

784

785

786

787

788

789

790

791

792

793

794

795

796

797

798

799

800

Thoracic sternum. T4-T7 with transverse plate without median process. T8 with posteromedial lobes in males.

Abdomen. Smooth, without small spinules on pleural margin of abdominal segments. All abdominal sternites with transverse ridge. First to third abdominal sternites with moderate triangular median process. Fifth sternite with median obtuse process. Preanal carina present, without small setae in males.

Telson (Fig. 7B). Moderately long $(6.7 \mathrm{~mm})$ andstraight. Dorsal surface with 2 pairs of spines. Cluster of setae present on antero-median part. Projection present on posterior margin, with two spines and plumose setae on each side. The inner pair of posterior spines longer than outer spines.

Uropods (Fig. 7B). Uropodal diaeresis with inner moveable spine, shorter than outer angle (Fig. 4B). Exopod longer than broad $(8.0: 3.7 \mathrm{~mm})$ and not reaching beyond the end of endopods.

Etymology. The specific name "puberimanus" is derived from the compound Latin words "puberis" for downy and "manus" for hand. It alludes to the long-tufted hairs on the second pereiopods.

Size. Males with larger body size than females; the largest male recorded being tl $60.0 \mathrm{~mm}$, cl $17.0 \mathrm{~mm}$; the largest female tl $28.9 \mathrm{~mm}$, cl $8.8 \mathrm{~mm}$; egg size is $1.7 \mathrm{~mm}$ in diameter.

Distribution. Recent populations are restricted to the northeastern part of Thailand and possibly occur in the Mekong River and its tributaries in Laos.

Remarks. This species is distributed commonly in tributaries of the middle Mekong River Basin in northeastern Thailand. The molecular phylogeny and morphological characters of $M$. puberimanus sp. nov. indicated close resemblance to $M$. dienbienphuense, which is commonly found in the Mekong River Basin, including Thailand, Laos, Cambodia (?), Vietnam, and also southern China (Hanamura et al. 2011). The characters distinguishing M. puberimanus sp. nov. from $M$. dienbienphuense are the number of finger teeth on the cutting edge of the major second pereiopod (11-16 vs. 18-32), spinulation on the anterior margin of carapace (absent vs. present), the spinulation on merus surface (sparse vs. abundant), and the slightly elongated carpus of second pereiopods (vs. highly elongated carpus).

Recently, a cavern-dwelling species was found from the central part of Thailand, namely $M$. spelaeus by Cai \& Vidthayanon (2016). The morphological characters indicate similarity with $M$. dienbienphuense in several aspects except for the form of the anterior rostrum, the reduced eye, the bilobed epistome and the second pereiopod being as long as the body. In this study, $M$. puberimanus sp. nov. shows morphological differences from the latter species by having less elongated carpus, distal part of rostrum not upturned, and merus of second pereiopods with less spinulation. The distribution of $M$. puberimanus sp. nov. seems associated with the open riverine system of the Mekong River Basin, whereas the distribution of M. spelaeus is restricted to subterranean limestone systems in the central part of Thailand. Two additional species that resemble $M$. dienbienphuense and are co-distributed in the Mekong River Basin are $M$. 
801 amplimanus and $M$. eriocheirum. Hanamura et al. (2011) reviewed the morphological characters 802 of these two species based on specimens from Laos and provided additional 16S rRNA

803

804

805

806

807

808

809

810

811

812

813

814

815

816

817

818

819

820

821

822

823

824

825

826

827

828

829

830

831

832

833

834

835

836

837

838

839

840

841

842

843

844

845

846

sequences for molecular phylogenetic analysis. In this study, the $16 \mathrm{~S}$ rRNA sequences of $M$. puberimanus sp. nov. were totally separated from Laotian M. amplimanus sequences, whereas M. eriocheirum from Laos nested within M. puberimanus sp. nov. samples (see Fig. S2 in supplement). However, the Laotian M. eriocheirum differs from $M$. eriocheirum sensu Dai (1984) in some aspects such as the number of dorsal and ventral rostrum teeth (9-12/2-3 vs. 1114/2-3 in Laotian specimens) and the number of teeth on fingers of second pereiopods (10 teeth vs. 11-17). For this reason, the samples called M. eriocheirum in Hanamura et al. (2011) herein are excluded from this study; either they are M. puberimanus sp. nov. or a separate species.

Key to mainland SE-Asian species in "pilimanus" species group (after Cai et al., 2004)

1. a) A rudimentary appendix interna present on the first male pleopod........ dalatense

b) A rudimentary appendix interna absent on the first male pleopod..................2

2. a) Merus of second pereiopods with pubescence................................5

b) Merus of second pereiopods without pubescence.............................

3. a) Rostrum short and convex distally, second pereiopods with fingers shorter than palm

b) Rostrum short and straight distally, second pereiopods with fingers shorter than

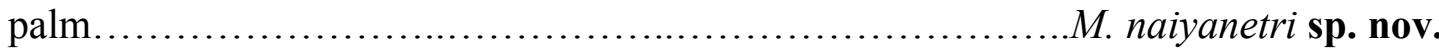

4. a) 17 small teeth on fingers of second pereiopod.......................... pilosum

b) $8-10$ blunt teeth on fingers of second pereiopod........................ sirindhorn

5. a) Tuberculation present on palm surface of second pereiopods...................6

b) Tuberculation absent on palm surface of second pereiopods...................10

6. a) Elongated carpus of major second pereiopod............................... 7

b) Cupped carpus of major second pereiopod............................. 8

7. a) Cutting edges of fingers of second pereiopod with 23-32 teeth, closed fingers without gap............................................ dienbienphuense

b) Cutting edges of fingers of second pereiopod with 11-16 teeth, closed fingers with gap................................................... puberimanus sp. nov.

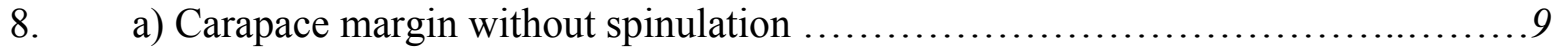

b) Carapace margin with spinulation

M. palmopilosum sp. nov.

9. a) Rostrum teeth arrangement $4+7 / 2$, cutting edges of fingers of second pereiopod 7-

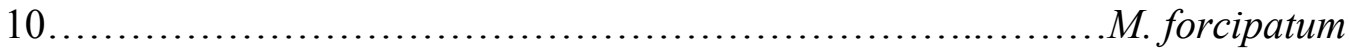

b) Rostrum teeth arrangement $6+7 / 2$, cutting edges of fingers of second pereiopod 11 -

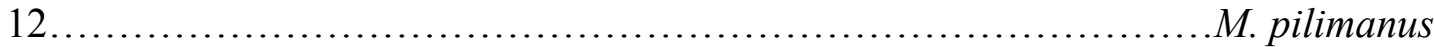

10. a) Epistome bilobed.......................................... hirsutimanus

b) Epistome trilobed...............................................11

11. a) Velvet pubescence on fingers and palm of second pereiopods........ eriocheirum

b) Densely tufted pubescence on fingers and palm of second pereiopods

.M. amplimanus

Using geometric-morphometric measurements, shape variation among species was detected by ten classical landmarks on the rostrum and carapace (Fig. S4). Canonical variates analysis (CVA) displayed sharp variation among nine species in the "pilimanus" group (Fig. S5). Shape variation between M. palmopilosom-M. naiyanetri was detected in both Procrustate and

Peer] reviewing PDF | (2020:03:47081:1:2:NEW 9 Sep 2020) 
847 Mahalanobis distance analyses. In terms of Mahalanobis distance, the comparison of shape 848 measurements resulted in seven paired species with statistical support $(\mathrm{P}<0.0001)$. A summary of 849 Procrustate and Mahalanobis distance analyses is given in Table S7.

\section{Discussion}

851

\section{Phylogenetic relationship of "pilimanus" species group members in mainland Southeast Asia}

The monophyletic status of genus Macrobrachium is still questionable based on samples of "pilimanus" members and other Macrobrachium species used in this study. The insertion of outgroups, Coralliocaris superba and Exopalaemon styliferus, within a clade of genus Macrobrachium contradicted previous phylogenetic studies indicating the separation of these two genera from genus Macrobrachium (Saengphan et al. 2018; Wowor et al. 2009). The selection of outgroup rooting is critical in phylogenetic analysis in order to clarify the evolutionary history of Macrobrachium species as indicated in previous reports (Murphy \& Austin 2005; Wowor et al. 2009). However, like this study, broad scale sampling of decapod phylogeny has shown that within family Palaemonidae, the genus Macrobrachium can be either nested with other genera such as Cryhiop, Exopalaemon and Palaemon or inserted within another closely related genus i.e. Leptopalaemon (Bracken 2009).

Molecular phylogenetic analysis of three partial gene datasets indicated at least ten different evolutionary lineages in the "pilimanus" species group. The two major clades (Fig 1) are usually found in mainland Southeast Asia tributaries; clade E consists of $M$. dienbienphuenses $+M$. Puberimanus sp. nov. $+M$. eriocheirum $+M$. hirsutimanus, and clade D consists of $M$. forcipatum $+M$. naiyanetri sp. nov. $+M$. palmopilosum sp. nov. $+M$. malayanum $+M$. pilimanus + M. sirindohrn. Macrobrachium sirindhorn is further grouped with M. pilimanus. The morphological characters of $M$. sirindhorn are quite unique and distinct from the congeners in this species group by having tufted setae on carpus and merus (except $M$. naiyanetri sp. nov., which has a group of stiff setae on the inner side of carpus and merus) and the distal downward pattern of rostrum. The distribution range of $M$. sirindhorn is questionable due to scattered records from northern Thailand and Laos. Another species that presents similar characters to $M$. sirindhorn is M. pilosum Cai and Dai, 1999 from southern China (Yunnan) and possibly northern Vietnam. Without genetic data of M. pilosum, we would keep these two as distinct valid species.

Macrobrachium species in clade E exhibited sympatric distribution in several river systems in north-central and eastern Thailand. Macrobrachium dienbienphuense and M. puberimanus sp. nov. exhibited elongated carpus of second pereiopods. However, the gap and slender shape of diagnostic characters of $M$. puberimanus sp. nov. The collected sample of $M$. puberimanus sp. nov. included a smaller number of individuals than for $M$. dienbienphuense in every locality. This finding might suggest a low population density of $M$. puberimanus sp. nov. in its natural habitat. 
890 In clade E, Macrobrachium hirsutimanus and M. eriocheirum are morphologically distinct from 891 each other by having incomplete covering of velvet setae on the palms of second pereiopods; 892 however, they typically co-exist in the Chaophraya River Basin of Thailand. Macrobrachium eriocheirum Dai, 1984 was originally described from Yunnan and recently treated as a synonym of M. dienbienphuense. In this study, specimens from Yunnan (M97-M98) indicated genetic compatibility with Thai samples by forming a monophyletic relationship. This finding might suggest the validity of $M$. eriocheirum as mentioned by previous taxonomic studies (Cai et al. 2004; Hanamura et al. 2011). In addition, the southern population of M. eriocheirum was collected from peninsular Thailand, extending the known distribution range of this species. A taxonomic review of $M$. hirsutimanus has been made and the neotype designation of this species was described using specimens from Nan Province, in northern Thailand (Cai et al. 2004). In this study, we sampled the northern riverine areas including the Nan River Basin to obtain a representative collection of specimens. The phylogenetic tree indicated a monophyletic group among molecular samples of M. hirsutimanus. However, there is another species from NorthCentral Thailand that is similar in morphological characters to $M$. hirsutimanus, namely $M$. spelaeus. The distribution of M. spelaeus is restricted to the underground freshwater system in a limestone cave; however, there may be some connection with the Nan River.

The mainland Southeast Asia "pilimanus" species group includes species from the southern peninsula of Thailand and a part of the Mekong River Basin (clade D). Macrobrachium forcipatum and M. malayanum exhibited small body length and short second pereiopods. Previously, two samples of M. malayanum were reported from Narathiwat, Southern Thailand (Cai et al. 2004). In this study, two genetically diverse lineages of M. Malayanum were found from the same locality. This might suggest the endemism of M. malayanum, which has restricted distribution in some natural habitats in the southern part of Thailand. The two new species in this study, $M$. naiyanetri sp. nov. and $M$. palmopilosum sp. nov. are grouped with $M$. pilimanus and M. sirindhorn; however, the phylogenetic relationship between these two species is questionable due to low statistical node support. Geographical differentiation in samples of M. naiyanetri sp. nov. was detected, and some species delimitation methods (ABGD, PTP and GMYC with mitochondrial loci) suggested the possibility of cryptic speciation for the two geographically different populations.

\section{Species boundary of "pilimanus" species group designated by morphological and molecular delimitation methods}

The Macrobrachium pilimanus group was initially proposed by Johnson (1960) and by the morphological concept, they shown the high morphologically complex group (Johnson 1963). The high phenotypical variation was previously observed by Holthuis (1950), who reported morphologically complex forms of a single species, Macrobrachium pilimanus. In M. pilimanus sensu stricto (Johnson 1963), the features used to diagnose this species from the two conspecific species (M. leptodactylus and M. malayanum) are the short fingers without a gap, inner edge of carpus of second pereiopods convex, and short rostrum. Geographical variation was detected in Javanian M. pilimanus and Bornean M. leptodactylus by either having a small number of teeth on rostrum or slightly different pattern of second pereiopods. The specimens were later re-examined, and found to be either the same species (Javanian M. pilimanus $=M$. leptodactylus; Ou \& Yeo (1995) or two distinct species (Bornean M. leptodactylus = M. urayang; 
936 (Wowor \& Short 2007). The type re-examination of some members in the "pilimanus" species

937

938

939

940

941

942

943

944

945

946

947

948

949

950

951

952

953

954

955

956

957

958

959

960

961

962

963

964

965

966

967

968

969

970

971

972

973

974

975

976

977

978

979

980

981

group show inappropriate species boundaries applied previously, or even the co-existence of unknown species within the type series, such as the specimens of M. malayanum in Johnson (1960); Johnson (1963) was found morphologically differ from type of M. malayanum by Roux (1934) (see taxonomic treatment in Chong \& Khoo (1987b)), while in another case, four paralectotype specimens of $M$. leptodactylus were found to be a distinct species, $M$. empulipke (see Wowor (2010)). In this study, a geometric morphometric examination of the M. pilimanus group was conducted for the first time. The use of measurable characters for species delimitation has been successful in several taxa with statistical confirmation (see Fig S4-5 and Table S6-7). Broad sampling, optimal specimens of each of the "pilimanus" members, and other landmark methods are required in further study. This study result would be relieved the alternative approach to delimit the species boundary of $M$. pilimanus group under morphological species concept.

The phylogenetic relationships within the M. pilimanus group have never been specifically investigated in order to verify the group's phylogenetic position and taxonomic validity. However, some members, including $M$. pilimanus, M. dienbienphuense, $M$. eriochierum, and M. amplimanus were previously included in several large-scale phylogenetic studies of genus Macrobrachium or higher taxa (Bracken et al. 2010; Jose \& Harikrishnan 2019; Liu et al. 2007; Pileggi \& Mantelatto 2010; Wowor et al. 2009). A taxonomic review of some "pilimanus" members based on molecular delimitation was done by Hanamura et al. (2011), and morphological identification was supported by the $16 \mathrm{~S}$ sequences to confirm the biological species concept. Using single genetic markers, the combination of available sequences from previous literature and newly amplified sequences from this study indicated unresolved phylogenetic relationships. The effect of long-branch attraction caused by gap insertion and short sequence length has been found in several database sequences. However, the M. pilimanus group shows a close evolutionary relationship with $M$. niphanae, another common species group found in mainland SE-Asia, based on the concatenated dataset.

In this study, the molecular delimitation using the optimum sequence dataset agreed well with traditional morphological classification despite the few diagnostic characters that have been observed in some nominal species. The monophyletic clade of each representative taxon detected from the concatenated dataset, including the three new species, was subsequently confirmed by automatic delimitation approaches based on single gene datasets (see Fig. 2). The BIN algorithm reflects the highest number of putative species in the COI dataset. According to the barcode gap threshold, over-estimation might be caused by genetic divergence of the dataset used, including the previously deposited sequences. The point of caution for BIN delimitation results in this study seems to be obscurity onthe species identification concept in several deposited sequences, especially in $M$. dienbienphuense. The genetic divergence among samples named $M$. dienbienphuense raises warning (max intraspecific divergence higher than Nearest-neighbor species; see Table S8) in barcode gap analysis. The BIN discordance also detects the noncompatibility of sequence divergence and BIN assignment which agree with the barcode gap threshold. In the case of $\mathrm{mPTP}$ and bPTP, the delimitation results showed moderate support for the designation of three new species found in this study. The clustering reassigned some "pilimanus" members to be a single species, as inferred in the 16S dataset under bPTP and mPTP. In the case of GMYC, the delimitation using COI and $16 \mathrm{~S}$ agreed with morphological identification and phylogenetic clade composition. In this study, all delimitation methods also

Peer] reviewing PDF | (2020:03:47081:1:2:NEW 9 Sep 2020) 
982 presented the warning of cryptic speciation in samples assigned as M. malayanum.

983 Unsurprisingly, low success in using 18S rRNA sequences was found with ABGD, PTP and

984 GMYC; clustering lumped members of the "pilimanus" group into one to three putative species.

985 Furthermore, the COI barcoding region seems to provide the fine resolution required for genus

986 Macrobrachium. This suggestion has also been reported in recent studies of DNA barcode

987 application on marine decapods, including Macrobrachium prawns (Hernawati et al. 2020;

988 Matzen da Silva et al. 2011).

989 The integrative approaches applied herein resolve the problems of morphological

990 concordance among "pilimanus" members. However, the species boundaries delimited by

991 traditional identification seem to be carefully interpreted when abundant samples were used for

992 comparison according to geographical variation. A combination of morphology and molecular

993 taxonomy approaches is recommended for future species delimitation in the M. pilimanus group

994 for the following reasons: first, the molecular operational taxonomic unit (MOTUs) is helpful to

995 accelerate the sample clustering process under traditional identification despite morphological

996 complexity; second, the phylogenetic species concept can be used to force the species

997 assignment and taxonomic validity when diagnostic characters of paired species are shown as

998 unclear; third, molecular taxonomy can provide supporting evidence of cryptic speciation.

\section{Species diversity and distribution of the Thai "pilimanus" species group}

Recent taxonomic reviews of Thai Macrobrachium species included nine species belonging to the "pilimanus" species group: M. eriocheirum, M. hirsutimanus, $M$. dienbienphuense, $M$. forcipatum, M. amplimanus, M. forcipatum, M. malayanum M. sirindhorn and M. spelaeus (Cai et al. 2004; Cai \& Vidthayanon 2016). In this study, seven previously recognised species were studied along with three new species that morphological and molecular datasets suggest should be grouped in the "pilimanus" species group. However, there are two nominated species in the Thai freshwater fauna that were not included in this study: $M$. amplimanus and M. spelaeus. The distribution of M. amplimanus has been reported from Thailand in four provinces, namely Chiang Mai, Loei, Kanchanaburi and Narathiwat (Cai, 2004); it is also present in Laos (Hanamura et al. 2011). Cai et al. (2004) reported that the characteristics of $M$. amplimanus are very similar to $M$. forcipatum and $M$. hirsutimanus in several aspects. The distinguishing features that can be used to identify M. amplimanus are the short rostrum, stoutlyinflated second pereiopods, and the number of rostrum teeth. The collected specimens from the Mekong River in this study indicated only two morphological species: M. dienbienphuense and M. puberimanus sp. nov. However, the available 16S DNA sequences in GenBank of $M$. amplimanus used in Hanamura et al. (2008) were initially combined with the 16S dataset in this study (Table S2 in appendix). The results indicated that the Laotian sequences of $M$. amplimanus sensu Hanamura et al. (2008) resembled species within the M. eriocheirum clade. To confirm the true taxonomic identity of these samples, new analyses using a combination of molecular markers are required due to high variation of sites detected in the 16S rRNA gene.

Macrobrachium spelaeus, the only Thai cavern species, was reported from Phra Wang Dang Cave in Phitsanulok Province (Cai \& Vidthayanon 2016). This species resembles $M$. dienbienphuense in morphology by having bilobed epistome, convex anterior rostrum, reduced eye, and by the length of the major second pereiopod being as long as the body. In this study, we could not find any specimens that resembled the morphology of M. spelaeus from central or 
1028

1029

1030

1031

1032

1033

1034

1035

1036

1037

1038

1039

1040

1041

1042

1043

1044

1045

1046

1047

1048

1049

1050

1051

1052

1053

1054

1055

1056

1057

1058

1059

1060

1061

1062

1063

1064

1065

1066

1067

1068

1069

1070

1071

1072

northern Thailand. Moreover, fresh materials for DNA analysis of this species is limited, and gaining access to the exact location of the type locality is difficult due to conservation efforts. However, the samples from neighboring rivers and small streams indicated two species that possibly co-exist with this species: M. eriocheirum and M. dienbienphuense.

Previously, the study of freshwater prawn genus Macrobrachium mainly focused on the commercial species due to their economic value both globally and at a local scale (New \& Nair 2012). Recently, two newly named species, $M$. suphanense and $M$. chinatense were described from freshwater tributaries in central Thailand (Saengphan et al. 2018; Saengphan et al. 2019). There is also some genetic evidence of Thai Macrobrachium species exhibiting distinct geographical populations (Khanarnpai et al. 2019; Saengphan et al. 2018). In total, thirty-one Macrobrachium species have been reported from Thailand, including the three new species found in this study. These findings suggest that the species diversity of freshwater fauna in Thailand has been under-reported and needs more attention. Furthermore, several native species of the genus Macrobrachium in Thailand and adjacent areas are of critical concern due to disturbance by anthropogenic activity, especially taxa in the "pilimanus" species group. The habitat preference of these prawn species is usually small streams or river systems connected to mountainous territory, which recently have been impacted by tourism and plantation development. The water quality and current flow of several riverine systems in mainland Southeast Asia are monitored under several environmental and ecological programs (Dudgeon 2000; Hughes 2017; Todd et al. 2010). Changes of the tributary system may cause the ecosystem to collapse by the disruption in species composition and loss of native freshwater fauna (Fukushima et al. 2014). However, the baseline data on biology, taxonomy and ecology are still insufficient. For this reason, further studies on biology, systematics and ecology of native Macrobrachium species are still required, especially in the context of biogeographical distribution related to migration, and river tributaries and their flows (de Bruyn et al. 2004; Wowor et al. 2009). The integration of recent novel methods such as molecular phylogeny, species distribution modeling and ecological monitoring methods would be beneficial for database implementation in conservation management of freshwater prawns at both local and regional scales (De Grave et al. 2008; De Grave et al. 2015; Michael 1988).

\section{Conclusion}

In this study, the integrative approach provided additional three new species of $M$. pilimanus members found in montain stream of Thailand. The species delimitation method related to biological and phylogenetic species concepts provided an alternative scheme for the justification of species boundary in this Macrobrachium species group. The geographical variation, refered both in molecular and morphological characteristics was documented in some species of M. pilimanus and would suggest the differences of dispersal abilities among congeneric species. The phylogenetic relationship among M. pilimanus members still be controversy due to non-monophyly but at least the mainland SE-Asian species united as monophyletic clade. The genetic variation based on this study and deposited samples suggests the possible cryptic fauna in Macrobrachium prawns from mainland SE-Asia where the massive network river basin was recognized. The distribution area of mainland M. pilimanus indicated the trend of species composition and abundant related to water flows from two basins; Chao Phraya and Mekong.

Peer) reviewing PDF | (2020:03:47081:1:2:NEW 9 Sep 2020) 


\section{Acknowledgements}

1074

1075 The authors would like to give sincere thanks to members of the Animal Systematics Research

1076

1077

1078

1079

1080

1081

1082

Unit, Chulalongkorn University (ASRU) and Animal Systematics and Molecular Ecology laboratory, Mahidol University (ASME) for kind support during field collecting and data analysis. Cordial thanks for accommodation and technical support during this study are given to all staff in the Department of Biology, Faculty of Science, Mahidol University. Field surveys in many restricted areas were supported by staff of the Department of National Parks, Wildlife and Plant Conservation. The authors would like to express our grateful thanks to reviewers for their constructive comments that improved the manuscript. 


\section{References}

1085 AVMA. 2013. AVMA guidelines for the euthanasia of animals. Available at https://www.avma.org/KB/Policies/Documents/euthanasia.pdf

1087

1088

1089

1090

1091

1092

1093

1094

1095

1096

1097

1098

1099

1100

1101

1102

1103

1104

1105

1106

1107

1108

1109

1110

Bate CS. 1868. On a new genus, with four new species, of freshwater prawns. Proceedings of the Zoological Society of London:363-368.

Bernardes SC, Pepato AR, von Rintelen T, von Rintelen K, Page TJ, Freitag H, and de Bruyn M. 2017. The complex evolutionary history and phylogeography of Caridina typus (Crustacea: Decapoda): long-distance dispersal and cryptic allopatric species. Scientific Reports 7:9044. 10.1038/s41598017-08494-w

Bracken GHD, De Grave, S., Felder, D. 2009. Phylogeny of the Infraorder Caridea Based on Mitochondrial and Nuclear Genes (Crustacea: Decapoda). In: Raton B, ed. Decapod Crustacean Phylogenetics: Taylor and Francis/CRC Press.

Bracken HD, De Grave S, Toon A, Felder DL, and Crandall KA. 2010. Phylogenetic position, systematic status, and divergence time of the Procarididea (Crustacea: Decapoda). Zoologica Scripta 39:198-212. 10.1111/j.1463-6409.2009.00410.x

Cai Y, and Dai AY. 1999. Freshwater shrimps (Crustacea : Decapoda : Caridea) from the Xishuangbanna region of Yunnan Province, southern China. Hydrobiologia 400:211-241. 10.1023/a:1003717109973

Cai Y, Naiyanetr P, and Ng PKL. 2004. The freshwater prawns of the genus Macrobrachium Bate, 1868, of Thailand (Crustacea: Decapoda: Palaemonidae). Journal of Natural History 38:581-649. 10.1080/0022293021000033238

Cai YX, and Liang XQ. 1999. Descriptions of three new species of freshwater shrimps (Crustacea : Decapoda : Atyidae) from Yunnan, Southern China. Raffles Bulletin of Zoology 47:73-80.

Cai YX, and Ng PKL. 2002. The freshwater palaemonid prawns (Crustacea : Decapoda : Caridea) of Myanmar. Hydrobiologia 487:59-83. 10.1023/a:1022991224381

Cai YX, and Shokita S. 2006. Report on a collection of freshwater shrimps (Crustacea : Decapoda : Caridea) from the Philippines, with descriptions of four new species. Raffles Bulletin of Zoology 54:245-270.

Cai YX, and Vidthayanon C. 2016. Macrobrachium spelaeus, a new species of stygobitic freshwater prawn from Thailand (Decapoda: Palaemonidae). Raffles Bulletin of Zoology 64:117-122.

Castelin M, Mazancourt V, Marquet G, Zimmerman G, and Keith P. 2017. Genetic and morphological evidence for cryptic species in Macrobrachium australe and resurrection of M. ustulatum (Crustacea, Palaemonidae). European Journal of Taxonomy 289. DO:10.5852/ejt.2017.289

Chen P, Tzeng T, Shih C, Chu T, and Lee Y. 2015. Morphometric variation of the oriental river prawn (Macrobrachium nipponense) in Taiwan. Limnologica 52:51-58. https://doi.org/10.1016/j.limno.2015.03.002

Chong SSC. 1989. A new species of freshwater prawn, Macrobrachium gua sp. nov. (Decapoda, Caridea, Palaemonidae) from Sabah, East Malaysia, Borneo. Crustaceana 56:31-38. 10.1163/156854089x00761

Chong SSC, and Khoo HW. 1987a. Macrobrachium ahkowi new-name a replacement name for Macrobrachium johnsoni Chong and Khoo, 1987 preoccupied by Macrobrachium johnsoni Ravindranath, 1979 (Decapoda, Caridea, palaemonidae). Zoologische Mededelingen 61:561-562 Chong SSC, and Khoo HW. 1987b. Macrobrachium malayanum (Roux, 1934) stat. nov. (Decapoda, Palaemonidae) as a synonym of $M$. geron Holthuis, 1950, with notes on its distribution. Journal of Natural History 21:903-913. 10.1080/00222938700770551

Dai AY. 1984. A preliminary study on the freshwater prawn genus Macrobrachium of China (Decapoda: Caridea). Acta Zootaxonomica Sinica 9:244-252. 
1131

1132

1133

1134

1135

1136

1137

1138

1139

1140

1141

1142

1143

1144

1145

1146

1147

1148

1149

1150

1151

1152

1153

1154

1155

1156

1157

1158

1159

1160

1161

1162

1163

1164

1165

1166

1167

1168

1169

1170

1171

1172

1173

1174

1175

1176

1177
Đăng NT, and Nguyen BY. 1972. Nouveaux genres, nouvelles espèces de la faune des invertébres des eaux douces et saumâtres du Nord Vietnam - Tap San Sinh Vat-Dia Hoc. Journal of Biology and Geology 6:155-162.

de Bruyn M, and Mather PB. 2007. Molecular signatures of Pleistocene sea-level changes that affected connectivity among freshwater shrimp in Indo-Australian waters. Molecular Ecology 16:42954307. 10.1111/j.1365-294X.2007.03481.x

de Bruyn M, Stelbrink B, Morley RJ, Hall R, Carvalho GR, Cannon CH, van den Bergh G, Meijaard E, Metcalfe I, Boitani L, Maiorano L, Shoup R, and von Rintelen T. 2014. Borneo and Indochina are Major Evolutionary Hotspots for Southeast Asian Biodiversity. Systematic biology 63:879-901. 10.1093/sysbio/syu047

de Bruyn M, Wilson JA, and Mather PB. 2004. Huxley's line demarcates extensive genetic divergence between eastern and western forms of the giant freshwater prawn, Macrobrachium rosenbergii. Molecular Phylogenetics and Evolution 30:251-257. 10.1016/S1055-7903(03)00176-3

De Grave S, Cai Y, and Anker A. 2008. Global diversity of shrimps (Crustacea: Decapoda: Caridea) in freshwater. Hydrobiologia 595:287-293. 10.1007/s10750-007-9024-2

De Grave S, Smith KG, Adeler NA, Allen DJ, Alvarez F, Anker A, Cai Y, Carrizo SF, Klotz W, Mantelatto FL, Page TJ, Shy J, Villalobos JL, and Wowor D. 2015. Dead Shrimp Blues: A Global Assessment of Extinction Risk in Freshwater Shrimps (Crustacea: Decapoda: Caridea). PloS one 10:e0120198. 10.1371/journal.pone.0120198

De Man JG. 1879. On some species of the genus Palaemon Fabr. with description of two new forms. Notes from the Leyden Museum 1:165-184.

De Man JG. 1892. Decapoden des Indischen Archipels. Zoologische Ergebnisse einer Reise in Niederlandisch Ost-Indien 2:265-527.

de Mazancourt V, Klotz W, Marquet G, Mos B, Rogers DC, and Keith P. 2019. The complex study of complexes: The first well-supported phylogeny of two species complexes within genus Caridina (Decapoda: Caridea: Atyidae) sheds light on evolution, biogeography, and habitat. Molecular Phylogenetics and Evolution 131:164-180. https://doi.org/10.1016/j.ympev.2018.11.002

DeSalle R, Gatesy J, Wheeler W, and Grimaldi D. 1992. DNA sequences from a fossil termite in OligoMiocene amber and their phylogenetic implications. Science 257:1933-1936.

Drummond A, and Rambaut A. 2007. BEAST: Bayesian evolutionary analysis by sampling trees. BMC Evol Biol 7:214.

Dudgeon D. 2000. The Ecology of Tropical Asian Rivers and Streams in Relation to Biodiversity Conservation. Annual Review of Ecology and Systematics 31:239-263.

Edgar R. 2004. MUSCLE: multiple sequence alignment with high accuracy and high throughput. Nucleic Acids Research 32:1792 - 1797.

Folmer O, Black M, Hoeh W, Lutz R, and Vrijenhoek R. 1994. DNA primers for amplification of mitochondrial cytochrome $\mathrm{c}$ oxidase subunit I from diverse metazoan invertebrates. Mol Mar Biol Biotechnol 3:294 - 299.

Fujisawa T, and Barraclough TG. 2013. Delimiting species using single-locus data and the generalized mixed yule coalescent approach: a revised method and evaluation on simulated data sets. Systematic biology 62:707 - 724 .

Fukushima M, Jutagate T, Grudpan C, Phomikong P, and Nohara S. 2014. Potential effects of hydroelectric dam development in the Mekong river basin on the migration of Siamese mud carp (Henicorhynchus siamensis and H. Lobatus) elucidated by otolith microchemistry. PloS one 9:e103722. 10.1371/journal.pone.0103722

Hammer $\varnothing$, Harper DAT, and Ryan PD. 2001. PAST: Paleontological statistics software package for education and data analysis. Palaeontologia Electronica 4:n.p.

Peer] reviewing PDF | (2020:03:47081:1:2:NEW 9 Sep 2020) 
1178

1179

1180

1181

1182

1183

1184

1185

1186

1187

1188

1189

1190

1191

1192

1193

1194

1195

1196

1197

1198

1199

1200

1201

1202

1203

1204

1205

1206

1207

1208

1209

1210

1211

1212

1213

1214

1215

1216

1217

1218

1219

1220

1221

1222

1223

1224

1225

Hanamura Y, Imai H, Lasasimma O, Souliyamath P, and Ito S. 2011. Freshwater prawns of the genus Macrobrachium Bate, 1868 (Crustacea, Decapoda, Palaemonidae) from Laos. Zootaxa:1-37.

Hernawati R, Nurhaman U, Busson F, Suryobroto B, Hanner R, Keith P, Wowor D, and Hubert N. 2020. Exploring community assembly among Javanese and Balinese freshwater shrimps (Atyidae, Palaemonidae) through DNA barcodes. Hydrobiologia 847:647-663. 10.1007/s10750-019-041277

Holthuis LB. 1950. The Decapoda of the Siboga-Expedition Part X. The Palaemonidae collected by the Siboga and Snellius Expeditions with remarks on other species. I. Subfamily Palaemoninae. Siboga Expeditie Leiden 39:1-267.

Holthuis LB. 1952. A general revision of the Palaemonidae (Crustacea, Decapoda, Natantia) of the Americas. II. The subfamily Palaemoninae. Occasional Papers of the Allan Hancock Foundation. $p$ 1-396.

Holthuis LB. 1955. The recent genera of the caridean and stenopodidean shrimps (Class Crustacea, order Decapoda, supersection Natantia) with keys for their determination. Zoologische Verhandelingen 26:1-157.

Holthuis LB. 1979. Cavernicolous and terrestrial decapod crustacea from Northern Sarawak, Borneo Zoologische Verhandelingen 171:1-47.

Huelsenbeck JP, and Hillis DM. 1993. Success of phylogenetic methods in the four taxon case. Systematic biology 42:247-264. http://dx.doi.org/10.1093/sysbio/42.3.247

Hughes AC. 2017. Understanding the drivers of Southeast Asian biodiversity loss. Ecosphere 8:e01624. 10.1002/ecs2.1624

Johnson DS. 1960. Sub-specific and intra-specific variation in some freshwater prawns of the Indo-Pacific region. In: Purchon RD, editor. Proceedings of the Centenary and Bicentenary Congress of Biology: University of Malaya Press. p 333.

Johnson DS. 1963. Distributional and other notes on some fresh-water prawns (Atyidae and Palaemonidae) mainly from the Indo-West Pacific region. Bulletin Natural History Museum State Singapore 32:5-30.

Jose D, and Harikrishnan M. 2019. Evolutionary history of genus Macrobrachium inferred from mitochondrial markers: a molecular clock approach. Mitochondrial DNA Part A 30:92-100. 10.1080/24701394.2018.1462347

Kapli P, Lutteropp S, Zhang J, Kobert K, Pavlidis P, Stamatakis A, and Flouri T. 2017. Multi-rate Poisson tree processes for single-locus species delimitation under maximum likelihood and Markov chain Monte Carlo. Bioinformatics (Oxford, England) 33:1630-1638. 10.1093/bioinformatics/btx025

Khanarnpai R, Thaewnon-ngiw B, and Kongim B. 2019. Genetic variation of Macrobrachium lanchesteri (De Man, 1911) in Northeastern Thailand. Cogent Biology 5:15. 10.1080/23312025.2019.1677126

Kumar S, Stecher G, and Tamura K. 2016. MEGA7: Molecular Evolutionary Genetics Analysis version 7.0 for bigger datasets. Molecular Biology and Evolution 33:1870-1874.

Larget B, and Simon DL. 1999. Markov chain Monte Carlo algorithms for the Bayesian analysis of phylogenetic trees. Molecular Biology and Evolution 16:750-759. http://dx.doi.org/10.1093/oxfordjournals.molbev.a026160

Li X, Liu, R., Liang, X., Chen, G. 2007. Fauna Sinica Invertebrata. Bejing: Science Press.

Liu J, Jiang J, Song S, Tornabene L, Chabarria R, Naylor GJP, and Li C. 2017. Multilocus DNA barcoding Species Identification with Multilocus Data. Scientific Reports 7:16601. 10.1038/s41598-01716920-2

Liu MY, Cai YX, and Tzeng CS. 2007. Molecular systematics of the freshwater prawn genus macrobrachium bate, 1868 (Crustacea: Decapoda: Palaemonidae) inferred from mtDNA sequences, with emphasis on east Asian species. Zoological Studies 46:272-289.

Peer] reviewing PDF | (2020:03:47081:1:2:NEW 9 Sep 2020) 
1226

1227

1228

1229

1230

1231

1232

1233

1234

1235

1236

1237

1238

1239

1240

1241

1242

1243

1244

1245

1246

1247

1248

1249

1250

1251

1252

1253

1254

1255

1256

1257

1258

1259

1260

1261

1262

1263

1264

1265

1266

1267

1268

1269

1270

1271

1272

Maddison WP, and Maddison DR. 2017. Mesquite: a modular system for evolutionary analysis. Available at http://mesquiteproject.org.

Matzen da Silva J, Creer S, dos Santos A, Costa AC, Cunha MR, Costa FO, and Carvalho GR. 2011. Systematic and Evolutionary Insights Derived from mtDNA COI Barcode Diversity in the Decapoda (Crustacea: Malacostraca). PloS one 6:e19449. 10.1371/journal.pone.0019449

Michael B. 1988. Freshwater Prawns: Status of global aquaculture, 1987. NACA Technical Manual No 6 A World Food Day Publication of the Network of Aquaculture Centres in Asia. Bangkok, Thailand.: Network of Aquaculture Centres in Asia. p 58.

Miller MA, Pfeiffer W, and Schwartz T. 2010. Creating the CIPRES Science Gateway for inference of large phylogenetic trees. the Gateway Computing Environments Workshop (GCE). New Orleans, Los Angles. p 1-8.

Murphy NP, and Austin CM. 2005. Phylogenetic relationships of the globally distributed freshwater prawn genus Macrobrachium (Crustacea: Decapoda: Palaemonidae): biogeography, taxonomy and the convergent evolution of abbreviated larval development. Zoologica Scripta 34:187-197. 10.1111/j.1463-6409.2005.00185.x

Naiyanetr P. 2001. Macrobrachium sirindhorn n. sp., a new freshwater prawn from northern Thailand (Decapoda, Caridea, Palaemonidae). Crustaceana 74:609-616. 10.1163/156854001750377885

Naiyanetr P. 2007. Checklist of crustacean fauna in Thailand (Decapoda, Stomatopoda, Anostraca, Myodocopa and Isopoda). Bangkok.

New MB, and Nair CM. 2012. Global scale of freshwater prawn farming. Aquaculture Research 43:960969. 10.1111/j.1365-2109.2011.03008.x

Ng PKL. 1994. On a collection of freshwater decapoda crustaceans from the Kinabatangan River, Sabah, Malaysia, with descriptions of three new species. Sabah Museum Journal 1:73-92.

Ng PKL. 1995. Freshwater decapod crustaceans (Potamidae, Palaemonidae) of Temengor Forest Reserve, Hulu Perak, Malaysia. Malayan Nature Journal 48:3-4.

Ou ACT, and Yeo DCJ. 1995. A new species of freshwater prawn, Macrobrachium platycheles (Decapoda, Caridea, Palaemonidae) from Singapore and Peninsular Malaysia. Raffles Bulletin of Zoology 43:299-308.

Palumbi SR. 1996. Nucleic acids II: the polymerase chain reaction. In: Hillis DM, Mable, B.K., Moritz, C., ed. Molecular systematics. Sunderland: Sinauer Associates, 205-247.

Parker SR. 1997. Sequence Navigator. Multiple sequence alignment software. Methods in Molecular Biology 70:54-145.

Pileggi LG, and Mantelatto FL. 2010. Molecular phylogeny of the freshwater prawn genus Macrobrachium (Decapoda, Palaemonidae), with emphasis on the relationships among selected American species. Invertebrate Systematics 24:194-208.

Pons J, Barraclough T, Gomez-Zurita J, Cardoso A, Duran D, Hazell S, Kamoun S, Sumlin W, and Vogler A. 2006. Sequence-based species delimitation for the DNA taxonomy of undescribed insects. Systematic biology 55:595 - 609.

Posada D. 2008. jModelTest: Phylogenetic model averaging. Molecular Biology and Evolution 25:1253 1256.

Puillandre N, Lambert A, Brouillet S, and Achaz G. 2012. ABGD, Automatic Barcode Gap Discovery for primary species delimitation. Mol Ecol 21:1864 - 1877.

Rafinesque CS. 1815. Analyse de la nature ou Tableau de l'univers et des corps organisés.: Palermo.

Rambaut A. 2009. FigTree version 1.3.1.

Ronquist F, Teslenko M, van der Mark P, Ayres D, Darling A, Hohna S, Larget B, Liu L, Suchard M, and Huelsenbeck J. 2012. MrBayes 3.2: Efficient bayesian phylogenetic inference and model choice across a large model space. Systematic biology 61:539 - 542.

Peer] reviewing PDF | (2020:03:47081:1:2:NEW 9 Sep 2020) 
1273

1274

1275

1276

1277

1278

1279

1280

1281

1282

1283

1284

1285

1286

1287

1288

1289

1290

1291

1292

1293

1294

1295

1296

1297

1298

1299

1300

1301

1302

1303

1304

1305

1306

1307

1308

1309

1310

1311

1312

1313

1314

1315

1316

1317

1318

1319

1320

Rossi N, MagalhÃes c, Mesquita ER, and Mantelatto FL. 2020. Uncovering a hidden diversity: a new species of freshwater shrimp Macrobrachium (Decapoda: Caridea: Palaemonidae) from Neotropical region (Brazil) revealed by morphological review and mitochondrial genes analyses. 2020 4732:19. 10.11646/zootaxa.4732.1.9

Rossi N, and Mantelatto FL. 2013. Molecular analysis of the freshwater prawn Macrobrachium olfersii (Decapoda, Palaemonidae) supports the existence of a single species throughout its distribution. PloS one 8:e54698-e54698. 10.1371/journal.pone.0054698

Roux J. 1934. New freshwater decapod crustaceans from the Malay Peninsula. Bulletin of the Raffles Museum 9:28-33.

Saengphan N, Panijpan B, Senapin S, Laosinchai P, Ruenwongsa P, Suksomnit A, and Phiwsaiya K. 2018. Morphology and molecular phylogeny of Macrobrachium suphanense sp. nov. (Decapoda: Palaemonidae) from Thailand. Zootaxa 4482:151-163. 10.11646/zootaxa.4482.1.7

Saengphan N, Panijpan B, Senapin S, Laosinchai P, Ruenwongsa P, Suksomnit A, and Phiwsaiya K. 2019. Macrobrachium chainatense sp. nov. (Decapoda: Palaemonidae): a freshwater prawn from Thailand based on morphology and molecular phylogeny. Zootaxa 4664:274-284. 10.11646/zootaxa.4664.2.9

Siriwut W, Edgecombe GD, Sutcharit C, and Panha S. 2015. The centipede genus Scolopendra in mainland Southeast Asia: Molecular phylogenetics, geometric morphometrics and external morphology as tools for species delimitation. PloS one 10:e0139182.

Stamatakis A. 2006. RAxML-VI-HPC: Maximum likelihood-based phylogenetic analyses with thousands of taxa and mixed models. Bioinformatics (Oxford, England) 22:2688 - 2690.

Suchard MA, Lemey P, Baele G, Ayres DL, Drummond AJ, and Rambaut A. 2018. Bayesian phylogenetic and phylodynamic data integration using BEAST 1.10. Virus Evolution 4:vey016. DOI:10.1093/ve/vey016

Tanabe AS. 2007. Kakusan: a computer program to automate the selection of a nucleotide substitution model and the configuration of a mixed model on multilocus data. Molecular Ecology Resources 77:962-964. http://dx.doi.org/10.1111/j.1471-8286.2007.01807.x

Tiwari KK. 1952. Diagnosis of new species and subspecies of the genus Palaemon Fabricius (Crustacea: Decapoda). Annals and magazine of natural history 5:27-32.

Todd PA, Ong X, and Chou LM. 2010. Impacts of pollution on marine life in Southeast Asia. Biodiversity and Conservation 19:1063-1082. 10.1007/s10531-010-9778-0

Venera-Pontón DE, Driskell AC, De Grave S, Felder DL, Scioli JA, and Collin R. 2020. Documenting decapod biodiversity in the Caribbean from DNA barcodes generated during field training in taxonomy. Biodiversity Data Journal 8:e47333. doi.org/10.3897/BDJ.8.e47333

von Rintelen K, von Rintelen T, and Glaubrecht M. 2007. Molecular phylogeny and diversification of freshwater shrimps (Decapoda, Atyidae, Caridina) from ancient Lake Poso (Sulawesi, Indonesia)-The importance of being colourful. Molecular Phylogenetics and Evolution 45:10331041. https://doi.org/10.1016/i.ympev.2007.07.002

Whiting MF, Carpenter JC, Wheeler QD, and Wheeler WC. 1997. The Strepsiptera problem: phylogeny of the holometabolous insect orders inferred from $18 \mathrm{~S}$ and $28 \mathrm{~S}$ ribosomal DNA sequences and morphology. Systematic biology 46:1-68.

Wowor D. 2010. Macrobrachium empulipk, a new freshwater prawn species (Decapoda, Palaemonidae) from Indonesia. Studies on Malacostraca: Lipke Bijdeley Holthuis Memorial Volume. Leiden: Brill, 715-726.

Wowor D, Muthu V, Meier R, Balke M, Cai Y, and Ng PKL. 2009. Evolution of life history traits in Asian freshwater prawns of the genus Macrobrachium (Crustacea: Decapoda: Palaemonidae) based on multilocus molecular phylogenetic analysis. Molecular Phylogenetics and Evolution 52:340-350. https://doi.org/10.1016/j.ympev.2009.01.002

Peer) reviewing PDF | (2020:03:47081:1:2:NEW 9 Sep 2020) 
1321 1322

Wowor D, and Ng PKL. 2007. The giant freshwater prawns of the Macrobrachium rosenbergii species group (Crustacea: Decapoda: Caridea: Palaemonidae). The Raffles Bulletin of Zoology 55:321. Wowor D, and Short JW. 2007. Two new freshwater prawns of the genus Macrobrachium Bate, 1868 (Crustacea : Decapoda : Palaemonidae) from the Kelian River, East Kalimantan, Indonesia. Raffles Bulletin of Zoology 55:77-87.

Xuân NV. 2012. Macrobrachium hungi, a new freshwater palaemonid prawn (Decapoda: Caridea: Palaemonidae) from the Tonle Sap Great Lake of Cambodia. Zootaxa:32-40.

Yeo DCJ, Cai, Y., Ng, P.K.L. 1999. The freshwater and terrestrial decapod Crustacea of Pulau Tioman, Peninsular Malaysia. Raffles Bulletin of Zoology:197-244.

Zhang J, Kapli P, Pavlidis P, and Stamatakis A. 2013. A general species delimitation method with applications to phylogenetic placements. Bioinformatics (Oxford, England) 29:2869-2876. 10.1093/bioinformatics/btt499 
Figure 1

Sampling localities of Macrobrachium pilimanus group in this study 







\section{Figure 2}

Phylogenetic tree based on concatenated dataset of three molecular genes (COI, 16S and $18 \mathrm{~S}$ rRNA), geographical distribution and morphological characteristics of second pereiopods of $M$. pilimanus species group.

(A) Phylogenetic tree (B) Morphological character of second pereiopods (C) Distribution area. Nodes of phylogenetic tree marked with empty circles indicate statistical support from both $\mathrm{ML}$ and BI (>70 bootstrap value and $>0.97$ posterior probability score); grey circles indicate statistical support from only one (either $\mathrm{ML}$ or $\mathrm{BI}$ ); asterisk indicates the sample obtained from NCBI. 
A

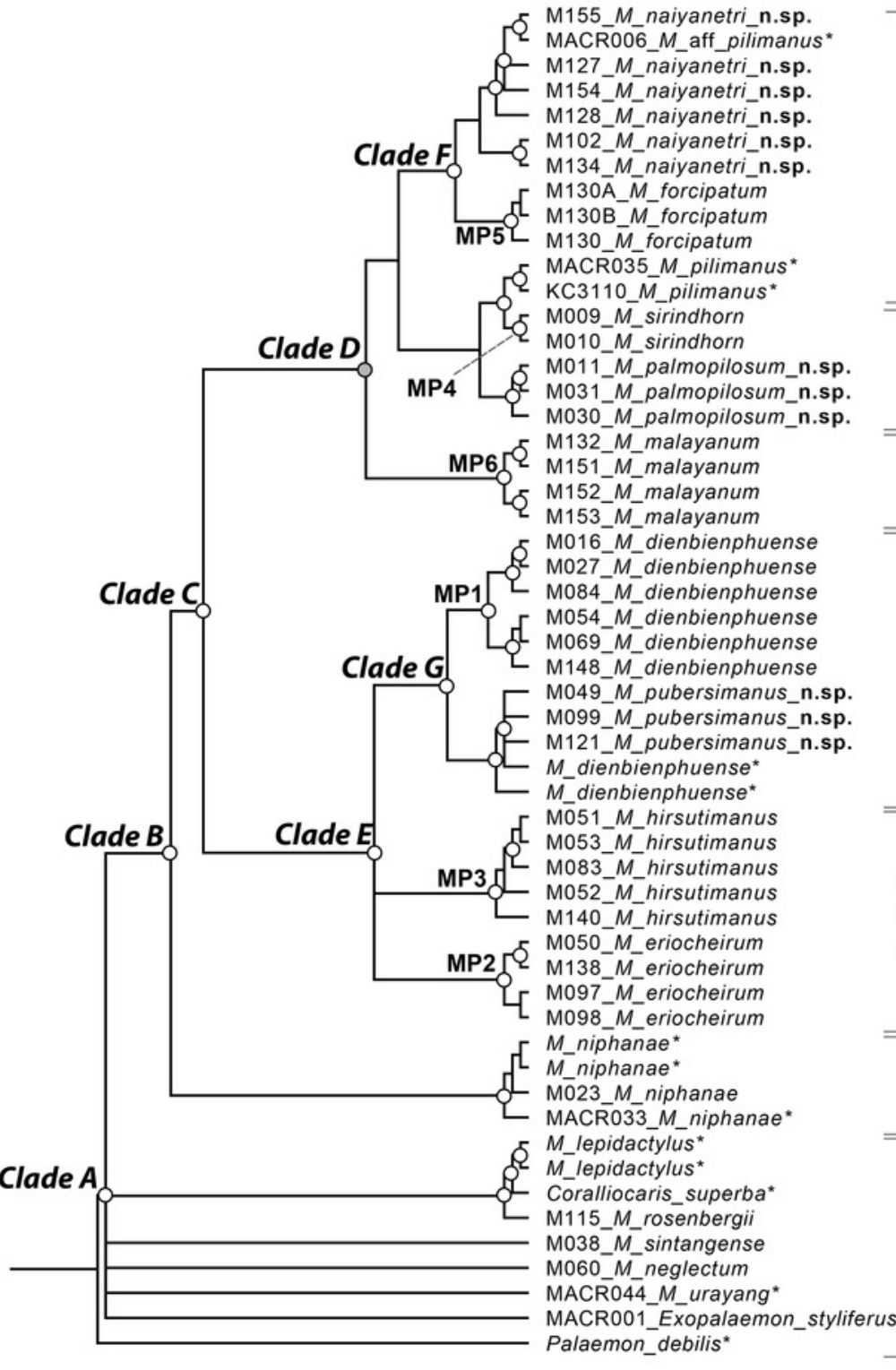

$\overline{0.5}$
B Morphology of second pereiopods

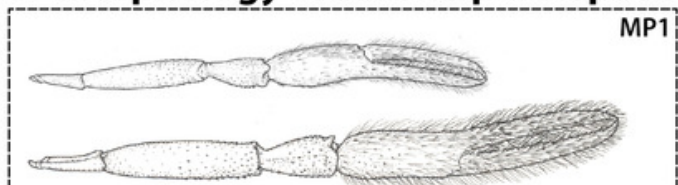

P
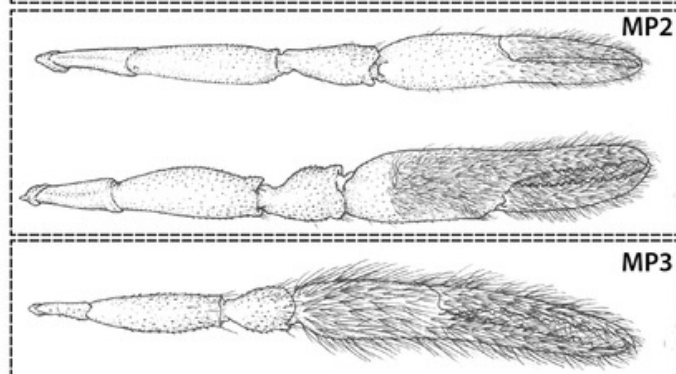

P
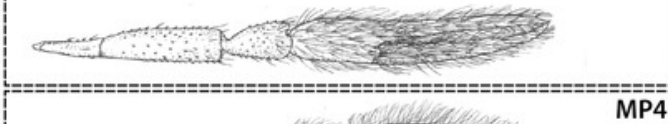

Mk
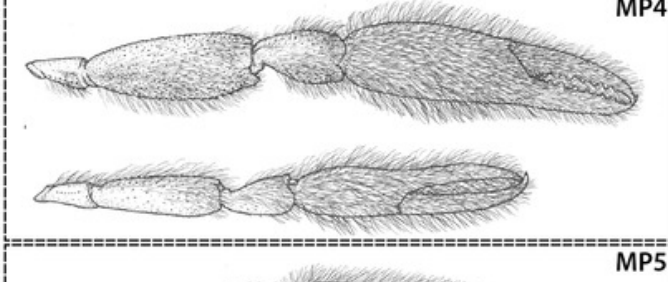

N

Mk

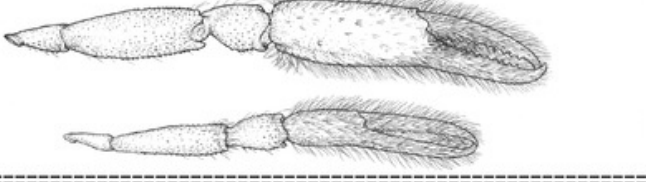

Mk

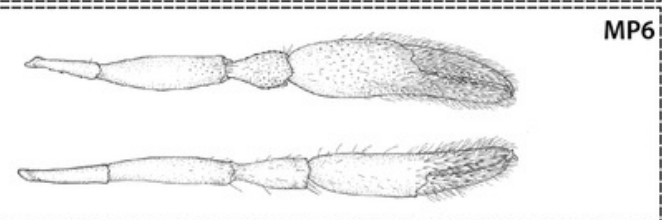

Dr

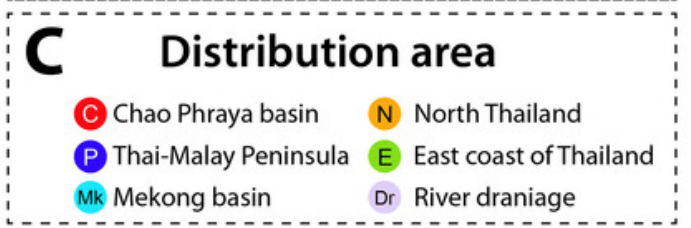




\section{Figure 3}

Results of species delimitation based on multiple approaches.

Abbreviations used on phylogenetic tree are as follow: Morpho, morphological identification;

PHYLO, phylogenetic analysis; BIN, BIN clustering in BOLD; ABGD, automated barcode gap; bPTP, Bayesian Poisson tree processes; mPTP, multi-rate Poisson Tree Processes; GMYC, Generalized Mixed Yule Coalescent model. Box colours indicate the split (red) and lumped (blue) species recognized by each species delimitation method. Grey boxes indicate nonmonophyly in phylogenetic analysis and missing sequences from dataset in each delimitation method; asterisk indicates the sample obtained from NCBI. 


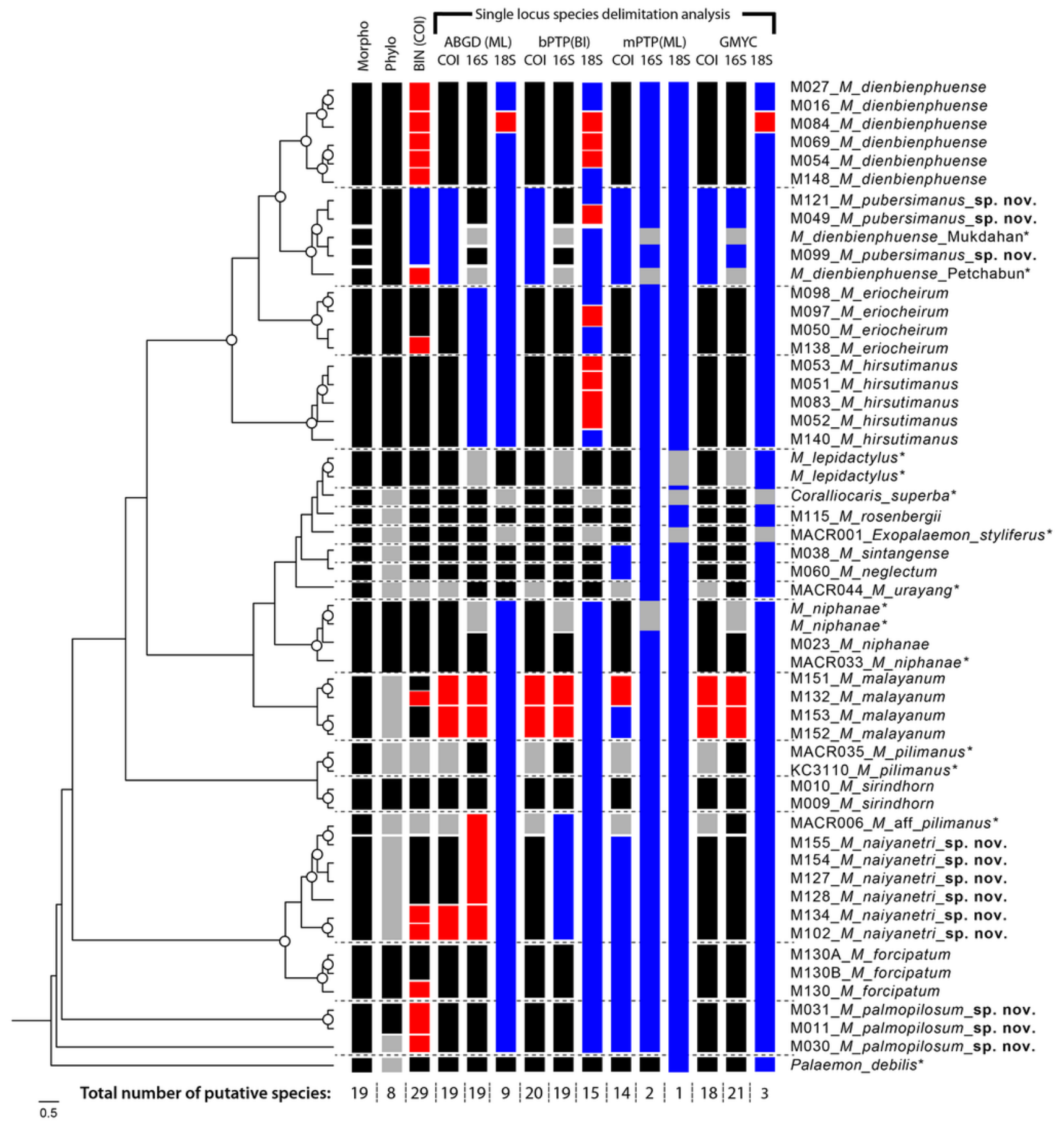


Figure 4

Live habitus specimens of three new Macrobrachium species in the $M$. pilimanus group from Thailand:

(A) Macrobrachium naiyanetri sp. nov. (B) Macrobrachium palmopilosum sp. nov. (C) Macrobrachium puberimanus sp. nov. 

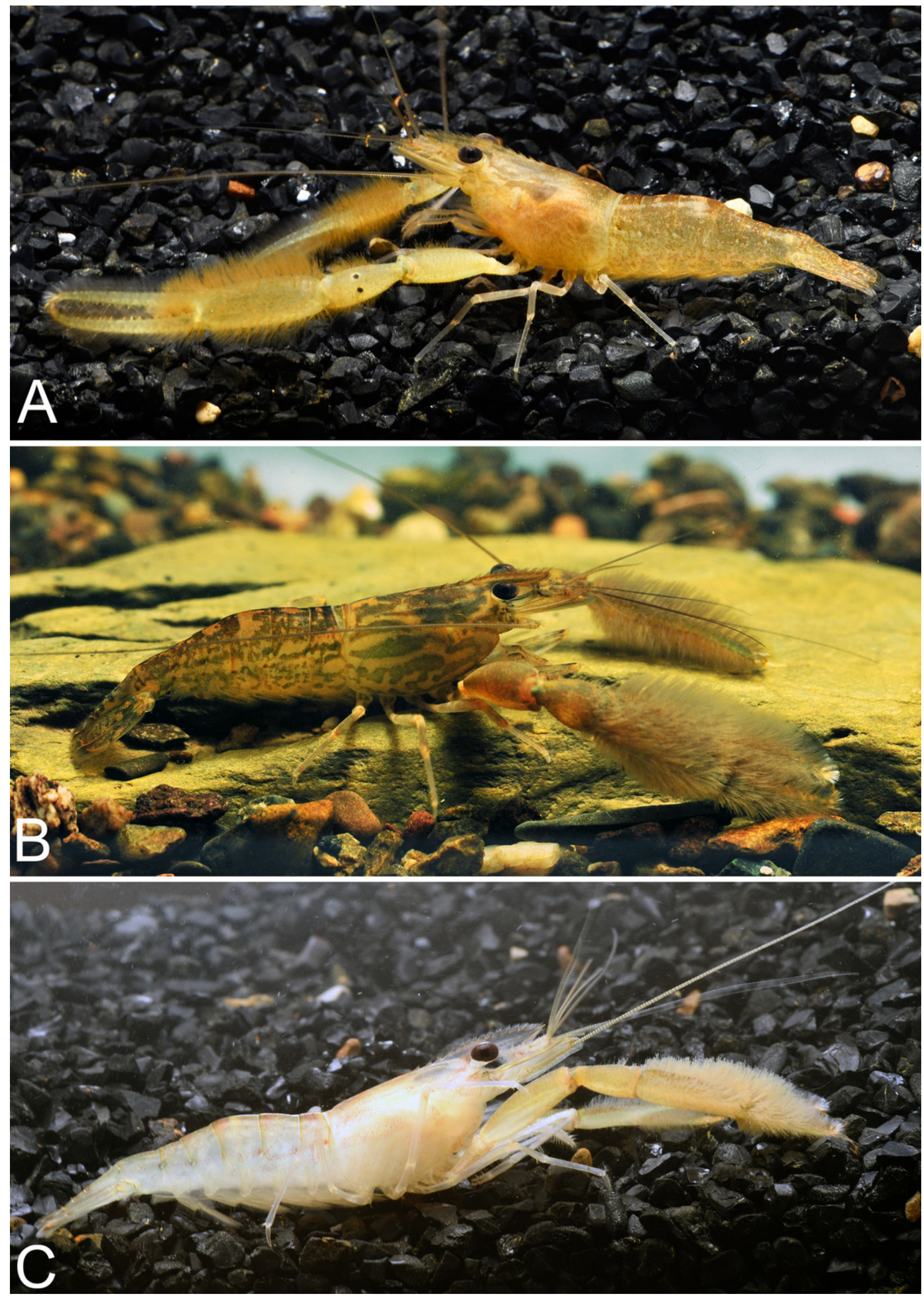
Figure 5

Morphological characters of Macrobrachium naiyanetri sp. nov. (A-G, I from holotype, $\mathrm{H}$ from paratype; CUMZ MP00003).

(A) Lateral view (B) Uropods (C) Carapace (D) Rostrum form and teeth (E) Major second pereiopod (F) Teeth on finger of major second pereiopod (G) Major second pereiopod length (H) Second pereiopods in female (I) Third pereiopod 

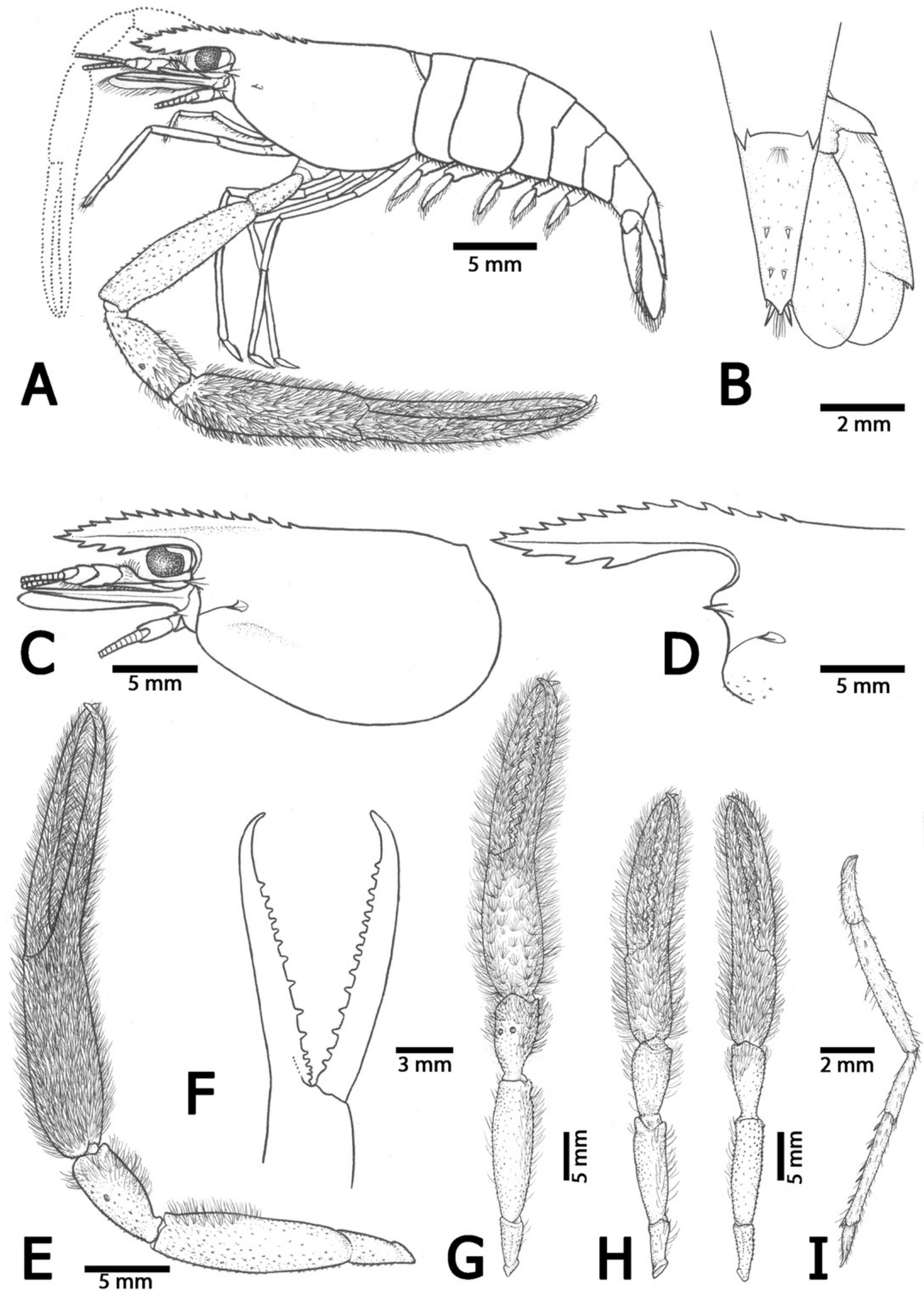

Peer) reviewing PDF | (2020:03:47081:1:2:NEW 9 Sep 2020) 
Figure 6

Morphological characters of Macrobrachium palmopilosum sp. nov. (A-G, I from holotype, $\mathrm{H}$ from paratype; CUMZ MP00008).

(A) Lateral view (B) Uropods (C) Carapace (D) Rostrum form and teeth (E) Major second pereiopod (F) Teeth on finger of major second pereiopod (G) Major second pereiopod length (H) Second pereiopods in female (I) Third pereiopod 


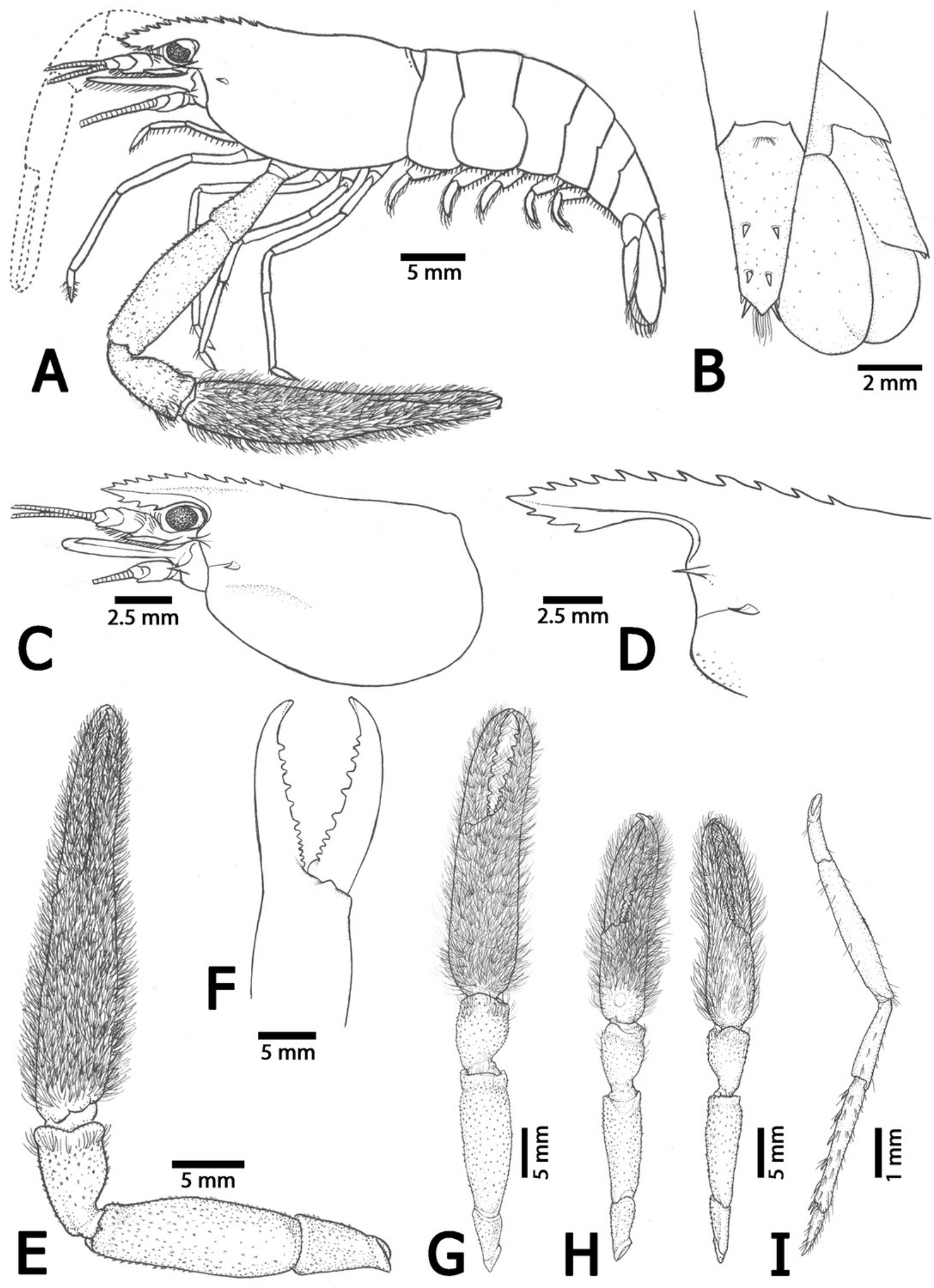




\section{Figure 7}

Morphological characters of Macrobrachium puberimanus sp. nov. (A-G, I from holotype, H from CUMZ MP00015).

(A) Lateral view (B) Uropods (C) Carapace (D) Rostrum form and teeth (E) Major second pereiopod (F) Teeth on finger of major second pereiopod (G) Major second pereiopod length (H) Second pereiopods in female (I) Third pereiopod 

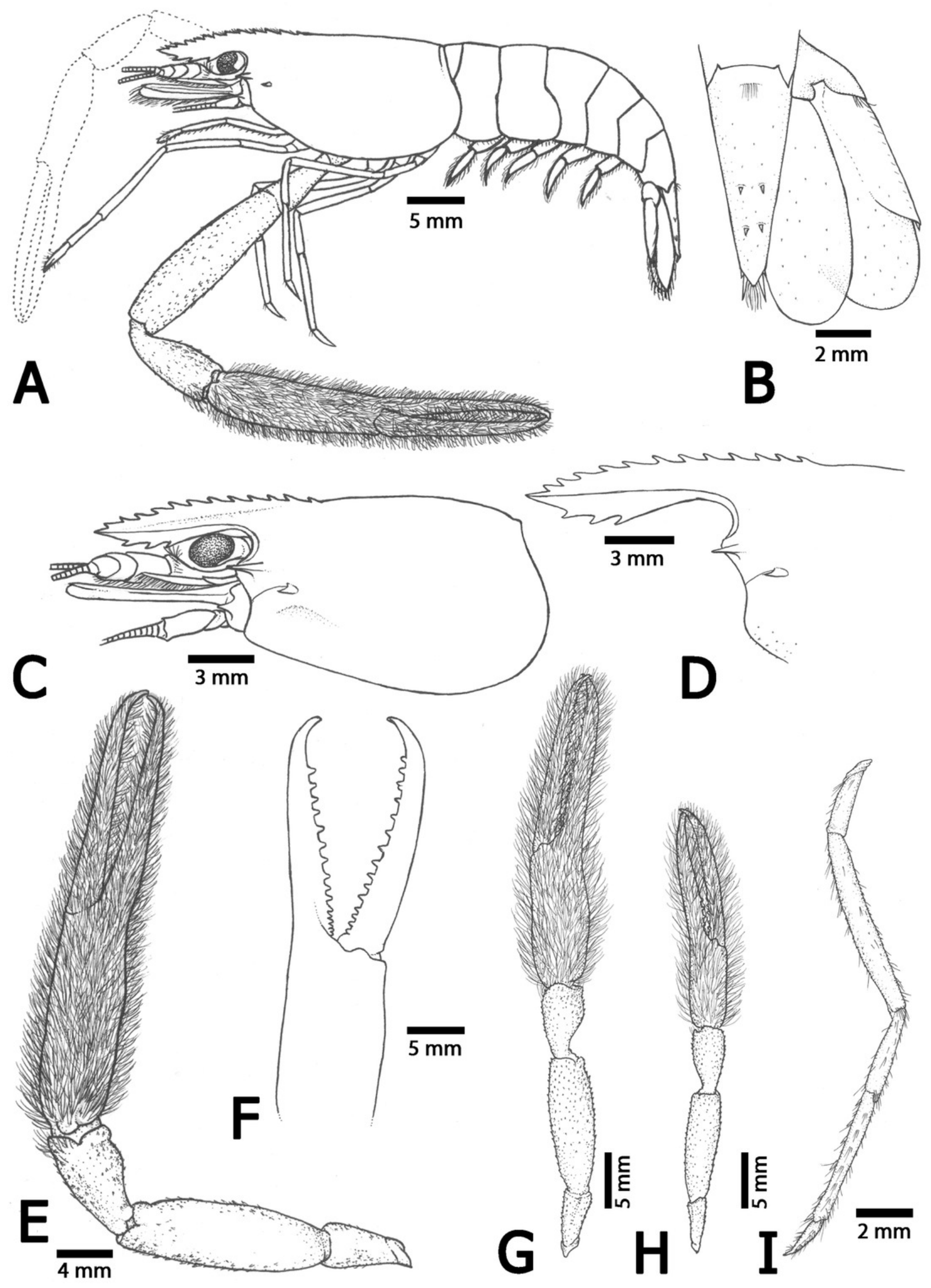

Peer) reviewing PDF | (2020:03:47081:1:2:NEW 9 Sep 2020) 


\section{Table $\mathbf{1}$ (on next page)}

Locality with geographic coordinates and GenBank accession numbers for specimens used for molecular phylogenetic analyses. 
1 Table 1. Locality with geographic coordinates and GenBank accession numbers for specimens used for 2 molecular phylogenetic analyses.

3

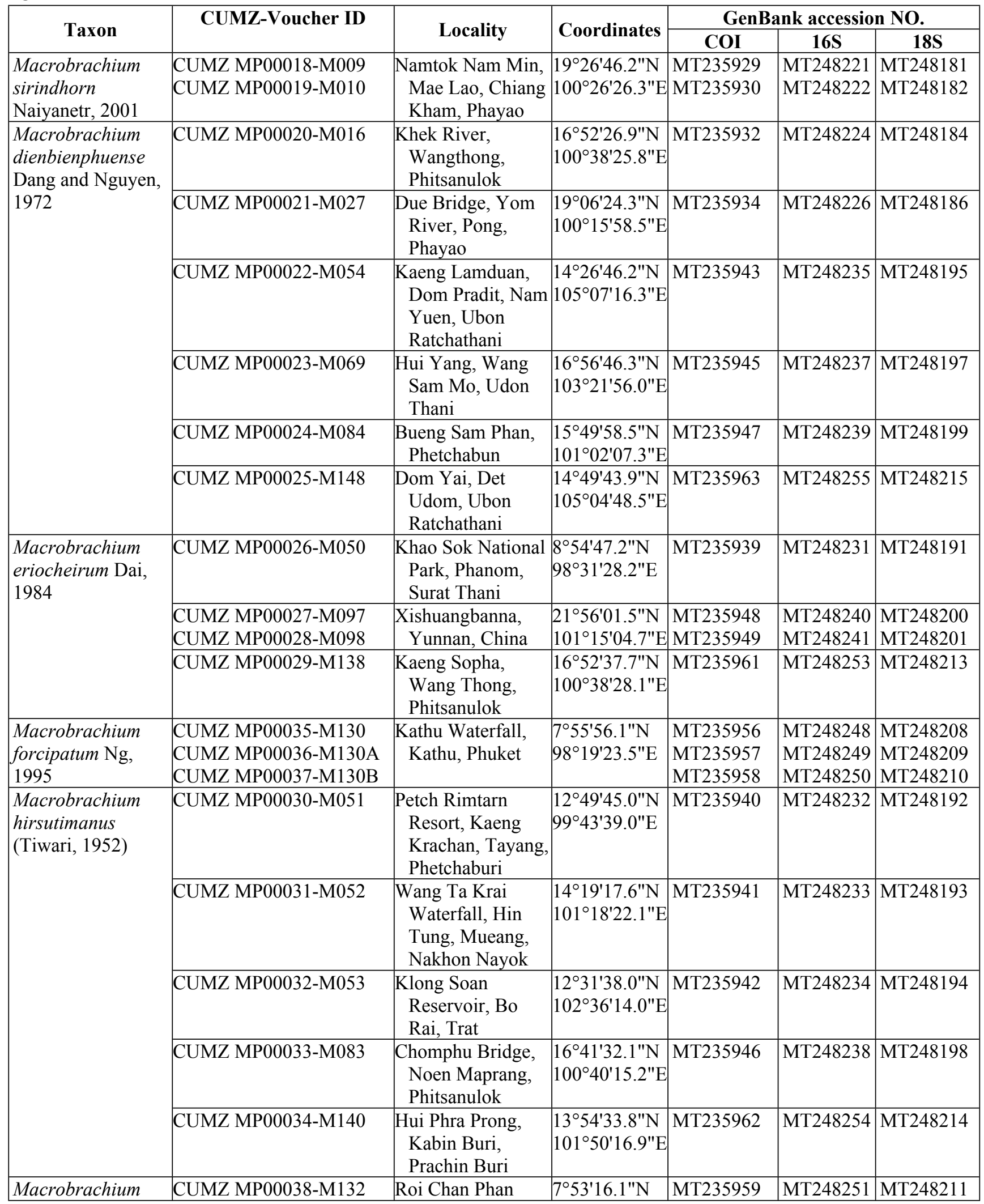




\begin{tabular}{|c|c|c|c|c|c|c|}
\hline $\begin{array}{l}\text { malayanum (Roux, } \\
\text { 1934) }\end{array}$ & $\begin{array}{l}\text { CUMZ MP00039-M151 } \\
\text { CUMZ MP00040-M152 } \\
\text { CUMZ MP00041-M153 }\end{array}$ & $\begin{array}{l}\text { Wang Waterfall, } \\
\text { Wang Wiset, } \\
\text { Trang }\end{array}$ & $99^{\circ} 19^{\prime} 54.4^{\prime \prime} \mathrm{E}$ & $\begin{array}{l}\text { MT235964 } \\
\text { MT235965 } \\
\text { MT235966 }\end{array}$ & $\begin{array}{l}\text { MT248256 } \\
\text { MT248257 } \\
\text { MT248258 }\end{array}$ & $\begin{array}{l}\text { MT248216 } \\
\text { MT248217 } \\
\text { MT248218 }\end{array}$ \\
\hline \multirow[t]{2}{*}{$\begin{array}{l}\text { Macrobrachium } \\
\text { naiyanetri sp. nov. }\end{array}$} & CUMZ MP00004-M102 & $\begin{array}{l}\text { Khao Banchob } \\
\text { Waterfall, } \\
\text { Makham, } \\
\text { Chanthaburi }\end{array}$ & $\begin{array}{l}12^{\circ} 51^{\prime} 04.5^{\prime \prime} \mathrm{N} \\
102^{\circ} 12^{\prime} 10.6 " \mathrm{E}\end{array}$ & MT235951 & MT248243 & MT248203 \\
\hline & $\begin{array}{l}\text { CUMZ MP00002-M127 } \\
\text { CUMZ MP00001-M128 } \\
\text { CUMZ MP00002-M154 } \\
\text { CUMZ MP00002-M155 }\end{array}$ & $\begin{array}{l}\text { Hui Prik, Cha- } \\
\text { wang, Nakhon Si } \\
\text { Thammarat }\end{array}$ & $\begin{array}{l}8^{\circ} 35^{\prime} 41.2^{\prime \prime} \mathrm{N} \\
99^{\circ} 27^{\prime} 55.6^{\prime \prime} \mathrm{E}\end{array}$ & $\begin{array}{l}\text { MT235954 } \\
\text { MT235955 } \\
\text { MT235967 } \\
\text { MT235968 }\end{array}$ & $\begin{array}{l}\text { MT248246 } \\
\text { MT248247 } \\
\text { MT248259 } \\
\text { MT248260 }\end{array}$ & $\begin{array}{l}\text { MT248206 } \\
\text { MT248207 } \\
\text { MT248219 } \\
\text { MT248220 }\end{array}$ \\
\hline $\begin{array}{l}\text { Macrobrachium } \\
\text { niphanae Shokita } \\
\text { and Takeda, } 1989\end{array}$ & CUMZ MP00042-M023 & $\begin{array}{l}\text { Nam Ko, Lom Sak, } \\
\text { Phetchabun }\end{array}$ & $\begin{array}{l}16^{\circ} 47^{\prime} 34.8^{\prime \prime} \mathrm{N} \\
101^{\circ} 10^{\prime} 34.8^{\prime \prime} \mathrm{E}\end{array}$ & MT235933 & MT248225 & MT248185 \\
\hline $\begin{array}{l}\text { Macrobrachium } \\
\text { neglectum }(\mathrm{De} \\
\text { Man, 1905) } \\
\end{array}$ & CUMZ MP00044-M060 & $\begin{array}{l}\text { Klong Chalung, } \\
\text { Mueang, Satun }\end{array}$ & \begin{tabular}{|l|}
$6^{\circ} 43^{\prime} 13.3^{\prime \prime} \mathrm{N}$ \\
$100^{\circ} 03^{\prime} 49.6^{\prime \prime} \mathrm{E}$
\end{tabular} & MT235944 & MT248236 & MT248196 \\
\hline \multirow{3}{*}{$\begin{array}{l}\text { Macrobrachium } \\
\text { palmopilosum } \mathrm{sp} . \\
\text { nov. }\end{array}$} & CUMZ MP00010-M011 & $\begin{array}{l}\text { Mae Mang, Bo } \\
\text { Kluea, Nan }\end{array}$ & $\begin{array}{l}19^{\circ} 08^{\prime} 12.7^{\prime \prime} \mathrm{N} \\
101^{\circ} 09^{\prime} 01.2^{\prime \prime} \mathrm{E}\end{array}$ & MT235931 & MT248223 & MT248183 \\
\hline & CUMZ MP00009-M030 & $\begin{array}{l}\text { Sob-Pue, Sa-Iap, } \\
\text { Song, Phrae }\end{array}$ & $\begin{array}{l}18^{\circ} 40^{\prime} 20.6^{\prime \prime} \mathrm{N} \\
100^{\circ} 13^{\prime} 26.1^{\prime \prime} \mathrm{E}\end{array}$ & MT235935 & MT248227 & MT248187 \\
\hline & CUMZ MP00007-M031 & $\begin{array}{l}\text { Tat Man } \\
\text { Waterfalls, Puea, } \\
\text { Chiang Klang, } \\
\text { Nan }\end{array}$ & $\begin{array}{l}19^{\circ} 17^{\prime} 11.9^{\prime \prime} \mathrm{N} \\
100^{\circ} 47^{\prime} 20.0^{\prime \prime} \mathrm{E}\end{array}$ & MT235936 & MT248228 & MT248188 \\
\hline \multirow[t]{3}{*}{$\begin{array}{l}\text { Macrobrachium } \\
\text { puberimanus sp. } \\
\text { nov. }\end{array}$} & CUMZ MP00015-M049 & $\begin{array}{l}\text { Nam Soam, Noan } \\
\text { Thong, Na Yung, } \\
\text { Udon Thani }\end{array}$ & $\begin{array}{l}18^{\circ} 00^{\prime} 30.5^{\prime \prime} \mathrm{N} \\
102^{\circ} 14^{\prime} 42.8^{\prime \prime} \mathrm{E}\end{array}$ & MT235938 & MT248230 & MT248190 \\
\hline & CUMZ MP00012-M099 & $\begin{array}{l}\text { Wat Tha Khaek, } \\
\text { Chiang Khan, } \\
\text { Loei }\end{array}$ & $\begin{array}{l}17^{\circ} 54^{\prime} 17.7^{\prime \prime} \mathrm{N} \\
101^{\circ} 40^{\prime} 58.4^{\prime \prime} \mathrm{E}\end{array}$ & MT235950 & MT248242 & MT248202 \\
\hline & CUMZ MP00014-M121 & Phu Ruea, Loei & \begin{tabular}{|l|}
$17^{\circ} 26^{\prime} 11.0^{\prime \prime} \mathrm{N}$ \\
$101^{\circ} 19^{\prime} 30.8^{\prime \prime} \mathrm{E}$
\end{tabular} & MT235953 & MT248245 & MT248205 \\
\hline $\begin{array}{l}\text { Macrobrachium } \\
\text { rosenbergii (De } \\
\text { Man, 1879) }\end{array}$ & CUMZ MP00045-M115 & $\begin{array}{l}\text { Klong Phon Rang, } \\
\text { Mueang, Ranong }\end{array}$ & $\begin{array}{l}9^{\circ} 53^{\prime} 12.5^{\prime \prime} \mathrm{N} \\
98^{\circ} 38^{\prime} 00.6^{\prime \prime} \mathrm{E}\end{array}$ & MT235952 & MT248244 & MT248204 \\
\hline $\begin{array}{l}\text { Macrobrachium } \\
\text { sirindhorn } \\
\text { Naiyanetr, } 2001\end{array}$ & $\begin{array}{l}\text { CUMZ MP00018-M009 } \\
\text { CUMZ MP00019-M010 }\end{array}$ & $\begin{array}{l}\text { Namtok Nam Min, } \\
\text { Mae Lao, Chiang } \\
\text { Kham, Phayao }\end{array}$ & $\begin{array}{l}19^{\circ} 26^{\prime} 46.2^{\prime \prime} \mathrm{N} \\
100^{\circ} 26^{\prime} 26.3^{\prime \prime} \mathrm{E}\end{array}$ & $\begin{array}{l}\text { MT235929 } \\
\text { MT235930 }\end{array}$ & $\begin{array}{l}\text { MT248221 } \\
\text { MT248222 }\end{array}$ & $\begin{array}{l}\text { MT248181 } \\
\text { MT248182 }\end{array}$ \\
\hline $\begin{array}{l}\text { Macrobrachium } \\
\text { sintangense (De } \\
\text { Man, 1898) }\end{array}$ & CUMZ MP00043-M038 & $\begin{array}{l}\text { Bang Ban, Phra } \\
\text { Nakhon Si } \\
\text { Ayutthaya }\end{array}$ & $\begin{array}{l}14^{\circ} 22^{\prime} 20.5^{\prime \prime} \mathrm{N} \\
100^{\circ} 28^{\prime} 55.8^{\prime \prime} \mathrm{E}\end{array}$ & MT235937 & MT248229 & MT248189 \\
\hline
\end{tabular}


Table 2 (on next page)

Details of primers used in this study ( $F=$ Forward, $R=$ Reverse) 
1 Table 2 Details of primers used in this study $(F=$ Forward, $R=$ Reverse $)$

2

\begin{tabular}{|c|l|l|l|}
\hline Gene & \multicolumn{1}{|c|}{ Primer name } & \multicolumn{1}{|c|}{ Sequence (5' to 3') } & \multicolumn{1}{c|}{ Reference } \\
\hline \multirow{2}{*}{ COI } & LCO1490 $(\mathrm{F})$ & GGT CAA CAA ATC ATA AAG ATA TTG G & Folmer et al. (1994) \\
\cline { 2 - 4 } & MacroNancy (R) & GCG GGT AGR ATT AAR ATR TAT ACT TC & This study \\
\hline \multirow{2}{*}{$16 \mathrm{~S}$} & $16 \mathrm{Sa}-\mathrm{L}(\mathrm{F})$ & CGC CTG TTT ATC AAA AAC AT & Palumbi (1996) \\
\cline { 2 - 5 } & $16 \mathrm{Sbr}-\mathrm{H} 2(\mathrm{R})$ & CTC CGG TTT GAA CTC AGA TCA & Palumbi (1996) \\
\hline \multirow{2}{*}{$18 \mathrm{~S}$} & $18 \mathrm{~S}-\mathrm{ai}(\mathrm{F})$ & CCT GAG AAA CGG CTA CCA CAT C & DeSalle et al. (1992) \\
\cline { 2 - 5 } & $18 \mathrm{~S}-\mathrm{bi}(\mathrm{R})$ & GAG TCT CGT TCG TTA TCG GA & Whiting et al. (1997) \\
\hline
\end{tabular}

3

4 


\section{Table 3 (on next page)}

Sequence annotation and DNA substitution model of each partial molecular marker used in this study 
1 Table 3. Sequence annotation and DNA substitution model of each partial molecular marker 2 used in this study.

3

\begin{tabular}{|l|l|l|l|l|l|}
\hline $\begin{array}{l}\text { Molecular } \\
\text { marker }\end{array}$ & $\begin{array}{l}\text { Sequence } \\
\text { length }\end{array}$ & $\begin{array}{l}\text { Conservative } \\
\text { site }\end{array}$ & Variable site & $\begin{array}{l}\text { Parsimony- } \\
\text { informative } \\
\text { site }\end{array}$ & $\begin{array}{l}\text { Substitution } \\
\text { model for } \\
\text { DNA } \\
\text { evolution }\end{array}$ \\
\hline COI & 678 & 428 & 250 & 228 & TIM2+I+G \\
\hline $16 \mathrm{~S}$ & 529 & 397 & 132 & 93 & TPM3uf $+\mathrm{G}$ \\
\hline $18 \mathrm{~S}$ & 678 & 428 & 250 & 228 & TIM1+I \\
\hline
\end{tabular}

4

5 


\section{Table 4 (on next page)}

Morphological comparison of three new species and the closely related species in the $M$. pilimanus group recorded from Thailand. 
1 Table 4. Morphological comparison of three new species and the closely related species in the 2 M. pilimanus species group recorded from Thailand. '*' indicates data were retrieved from

3 original description and "?" were data deficiency.

\begin{tabular}{|c|c|c|c|c|c|c|c|}
\hline \multirow[b]{2}{*}{ Characters } & \multicolumn{7}{|c|}{ Species } \\
\hline & $\begin{array}{c}M . \\
\text { niyanetri } \\
\text { sp. nov }\end{array}$ & $\begin{array}{c}\text { M. } \\
\text { palmopilos } \\
\text { um sp. } \\
\text { nov }\end{array}$ & $\begin{array}{c}\text { M. } \\
\text { puberima } \\
\text { nus sp. } \\
\text { nov }\end{array}$ & $\begin{array}{c}\text { M. } \\
\text { ampliman } \\
u s^{*}\end{array}$ & $\begin{array}{c}\text { M. } \\
\text { dienbienphue } \\
\text { nse }\end{array}$ & $\begin{array}{c}\text { M. } \\
\text { hirsutiman } \\
\text { us } *\end{array}$ & $\begin{array}{c}M . \\
\text { eriochier } \\
\text { um }\end{array}$ \\
\hline Rostrum teeth & $8-14 / 2-4$ & $10-12 / 2-3$ & $12-15 / 3$ & $9-12 / 2$ & $8-14 / 1-3$ & $10 / 2$ & $10-13 / 2-3$ \\
\hline $\begin{array}{l}\text { Rostrum } \\
\text { reaching end } \\
\text { of antenular } \\
\text { peduncle }\end{array}$ & $\begin{array}{l}\text { Not } \\
\text { reaching } \\
\text { to the end }\end{array}$ & $\begin{array}{l}\text { Not } \\
\text { reaching to } \\
\text { the end }\end{array}$ & $\begin{array}{l}\text { Reaching } \\
\text { to the end }\end{array}$ & $\begin{array}{l}\text { Not } \\
\text { reaching } \\
\text { to the end }\end{array}$ & $\begin{array}{l}\text { Reaching to } \\
\text { the end }\end{array}$ & $\begin{array}{l}\text { Not } \\
\text { reaching to } \\
\text { the end }\end{array}$ & $\begin{array}{l}\text { Not } \\
\text { reaching } \\
\text { to the end }\end{array}$ \\
\hline $\begin{array}{l}\text { Spinule on } \\
\text { margin of } \\
\text { carapace }\end{array}$ & present & present & absent & present & $\begin{array}{l}\text { present/absen } \\
\mathrm{t}\end{array}$ & absent & absent? \\
\hline Epistome & trilobed & bilobed & trilobed & trilobed & trilobed & bilobed & trilobed \\
\hline $\begin{array}{l}\text { Tuberculation/s } \\
\text { pine on palm } \\
\text { surface of } \\
\text { second } \\
\text { pereiopods }\end{array}$ & absent & present & present & present? & present & absent & absent \\
\hline $\begin{array}{l}\text { Length of male } \\
\text { second } \\
\text { pereiopods }\end{array}$ & unequal & unequal & unequal & unequal & unequal & unequal & unequal \\
\hline $\begin{array}{l}\text { Segment of } \\
\text { major second } \\
\text { pereiopod }\end{array}$ & $\begin{array}{l}\text { Fing. }>\text { Pal } \\
\text { Pal }>\text { Carp. } \\
\text { Carp }<\text { Me } \\
\text { r. } \\
\text { Pal. } \\
=\text { Mer. }\end{array}$ & $\begin{array}{l}\text { Fing. }<\text { Pal. } \\
\text { Pal. }>\text { Carp. } \\
\text { Carp. }<\text { Mer } \\
\text { Pal. } \leq \text { Mer. }\end{array}$ & $\begin{array}{l}\text { Fing. }>\text { Pal. } \\
\text { Pal }>\text { Carp. } \\
\text { Carp. }<\text { Me } \\
\text { r. } \\
\text { Pal. } \\
=\text { Mer. }\end{array}$ & $\begin{array}{l}\text { Fing. }=\text { Pal. } \\
\text { Pal }>\text { Carp. } \\
\text { Carp. }<\text { Me } \\
\text { r. } \\
\text { Pal. } \geq \\
\text { Mer. }\end{array}$ & $\begin{array}{l}\text { Fing.>Pal. } \\
\text { Pal }>\text { Carp. } \\
\text { Carp. }<\text { Mer. } \\
\text { Pal. } \geq \text { Mer. }\end{array}$ & $\begin{array}{l}\text { Fing. }<\text { Pal. } \\
\text { Pal } \geq \text { Carp. } \\
\text { Carp. }<\text { Mer } \\
\text {. } \\
\text { Pal. } \geq \text { Mer. }\end{array}$ & $\begin{array}{l}\text { Fing. } \\
\geq \text { Pal. } \\
\text { Pal }>\text { Carp } \\
\text {. } \\
\text { Carp. }<\text { M } \\
\text { er. } \\
\text { Pal. } \\
=\text { Mer. }\end{array}$ \\
\hline Carpus shape & $\begin{array}{l}\text { Slightly } \\
\text { elongate/c } \\
\text { up }\end{array}$ & cup & elongate & cup & elongate & cup & cup \\
\hline $\begin{array}{l}\text { Teeth on } \\
\text { dactylus (Dt) } \\
\text { and pollex }(\mathrm{Pt})\end{array}$ & $\begin{array}{l}\text { Dt: } 10-18 \\
\text { Pt:10-18 }\end{array}$ & $\begin{array}{l}\text { Dt:10-12 } \\
\text { Pt:10-11 }\end{array}$ & $\begin{array}{l}\mathrm{Dt}: 11-16 \\
\mathrm{Pt}: 10-14\end{array}$ & $\begin{array}{l}\text { Dt: } 13 \\
\text { Pt:13 }\end{array}$ & $\begin{array}{l}\mathrm{Dt}: 20-32 \\
\mathrm{Pt}: 20-32\end{array}$ & $\begin{array}{l}\mathrm{Dt}: 15 \\
\mathrm{Pt}: 15\end{array}$ & $\begin{array}{l}\text { Dt: } 12-15 \\
\text { Pt:12-15 }\end{array}$ \\
\hline $\begin{array}{l}\text { Gap in closed } \\
\text { fingers }\end{array}$ & gapping & gapping & gapping & $\begin{array}{l}\text { Not } \\
\text { gapping }\end{array}$ & Not gapping & $\begin{array}{l}\text { Slightly } \\
\text { gapping }\end{array}$ & $\begin{array}{l}\text { Slightly } \\
\text { gapping }\end{array}$ \\
\hline $\begin{array}{l}\text { Moveable spine } \\
\text { on uropodal } \\
\text { diaraesis }\end{array}$ & $\begin{array}{l}\text { Equally to } \\
\text { outer } \\
\text { angle }\end{array}$ & $\begin{array}{l}\text { Shorter } \\
\text { than outer } \\
\text { angle }\end{array}$ & $\begin{array}{l}\text { Shorter } \\
\text { than outer } \\
\text { angle }\end{array}$ & $\begin{array}{l}\text { Shorter } \\
\text { than outer } \\
\text { angle }\end{array}$ & $\begin{array}{l}\text { Shorter than } \\
\text { outer angle }\end{array}$ & $\begin{array}{l}\text { Shorter } \\
\text { than outer } \\
\text { angle }\end{array}$ & $\begin{array}{l}\text { Shorter } \\
\text { than } \\
\text { outer } \\
\text { angle }\end{array}$ \\
\hline
\end{tabular}


